\title{
Promising nanotherapy in treating leishmaniasis
}

\author{
Aline de Souza $^{a}$, Débora Soares Souza Marins ${ }^{a}$, Samir Leite Mathias ${ }^{b}$, Lis Marie Monteiro ${ }^{a}$, \\ Megumi Nishitani Yukuyama ${ }^{\mathrm{a}}$, Cauê Benito Scarim ${ }^{\mathrm{c}}$, Raimar Löbenberg ${ }^{\mathrm{d}}$, \\ Nádia Araci Bou-Chacra, ${ }^{\text {a,* }}$ \\ a University of São Paulo, Faculty of Pharmaceutical Sciences, Prof. Lineu Prestes Avenue, 580, Bl-13/15, 05508-900 São Paulo, SP, Brazil \\ ${ }^{\mathrm{b}}$ Federal University of São Carlos, Department of Physics, Chemistry and Mathematics, João Leme dos Santos Highway, Km 110, 18052-780 Sorocaba, SP, Brazil \\ “ São Paulo State University “Júlio de Mesquita Filho”- UNESP, Faculty of Pharmaceutical Sciences, Department of Drugs and Medicines, Rodovia Araraquara Jaú, Km 01 \\ - s/n, 14800-903 Araraquara, SP, Brazil \\ ${ }^{\mathrm{d}}$ University of Alberta, Faculty of Pharmacy and Pharmaceutical Sciences, Edmonton, AB T6G 2N8, Canada
}

\section{A R T I C L E IN F O}

\section{Keywords:}

Nanotechnology

Human leishmaniasis

Treatment

Nanotherapeutics

Drug targeting

Drug delivery systems

\begin{abstract}
A B S T R A C T
Leishmaniases are infectious diseases caused by an intracellular protozoan in humans by 20 different species of Leishmania among more than 53 species. There are at least twelve million cases of infections worldwide and three hundred and fifty million people are at risk in at least 98 developing countries in Africa, South-East Asia, and the Americas. Only Brazil presented high burden for both visceral leishmaniasis (VL) and cutaneous (CL). Chemotherapy is the main means of dealing with this infection. Nevertheless, only a few effective drugs are available, and each has a particular disadvantage; toxicity and long-term regimens compromise most chemotherapeutic options, which decreases patient compliance and adherence to the treatment and consequently the emergence of drug-resistant strains. Nano drug delivery systems (NanoDDS) can direct antileishmanial drug substances for intracellular localization in macrophage-rich organs such as bone marrow, liver, and spleen. This strategy can improve the therapeutic efficacy and reduce the toxic effects of several antileishmanial drug substances. This review is an effort to comprehensively compile recent findings, with the aim of advancing understanding of the importance of nanotechnology for treating leishmaniases.
\end{abstract}

\section{Introduction}

Neglected tropical diseases (NTDs) are a diverse group of infectious diseases that are predominant in the poorest parts of the world. These diseases are prevalent in tropical and subtropical areas due to insufficient health infrastructures. There are currently 20 NTDs prevalent in 149 countries, affecting approximately one billion people worldwide (World Health Organization, 2016a). Among the NTDs, there are at least seven hundred thousand new leishmaniasis cases and twenty thousand deaths annually worldwide.

Leishmaniasis presents three main forms, visceral (VL), also known as kala-azar, cutaneous (CL) and mucocutaneous leishmaniasis (MCL). The average ratio of incidents between the cutaneous and visceral forms, respectively the common and the fatal form, is approximately 8 times (Herwaldt, 1999; World Health Organization, 2017). There are approximately twelve million cases of infections worldwide and three hundred and fifty million people are at risk in 98 developing countries from Africa, South-East Asia and the Americas (Akhoundi et al., 2016; World Health Organization, 2016b).

In 2015, six regions were reported to have higher cases of CL and VL by the WHO (Europe, Western Pacific, the Americas, Southeast Asia, eastern Mediterranean and Africa), 87 countries were considered

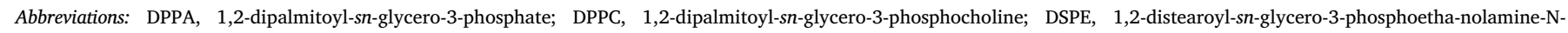

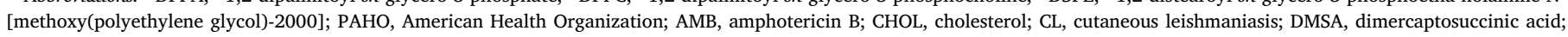

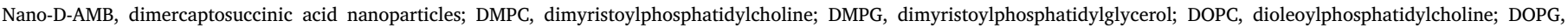

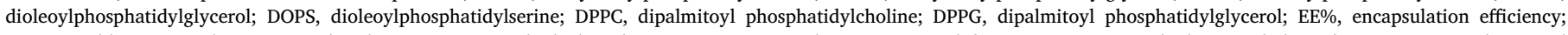

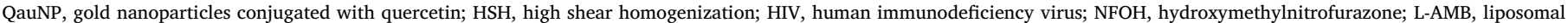

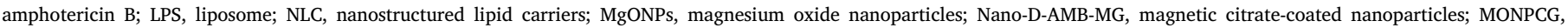

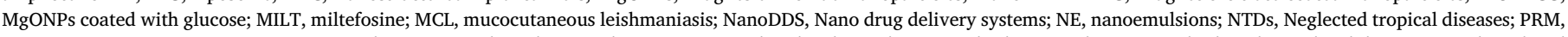

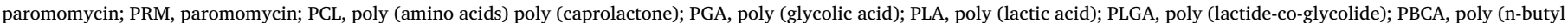

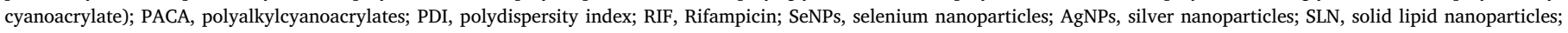
SESE, spontaneous emulsification and solvent evaporation; TiAgNps, titanium dioxide and silver nanoparticles; TFL-L, trifluralin liposome; VL, visceral leishmaniasis

* Corresponding author at: 580, Prof. Lineu Prestes Avenue, Bl-13/15, 05508-900 São Paulo, SP, Brazil.

E-mail addresses: aline_souza@usp.br (A. de Souza), debora_marins@usp.br (D.S.S. Marins), raimar@ualberta.ca (R. Löbenberg), chacra@usp.br (N.A. Bou-Chacra). 


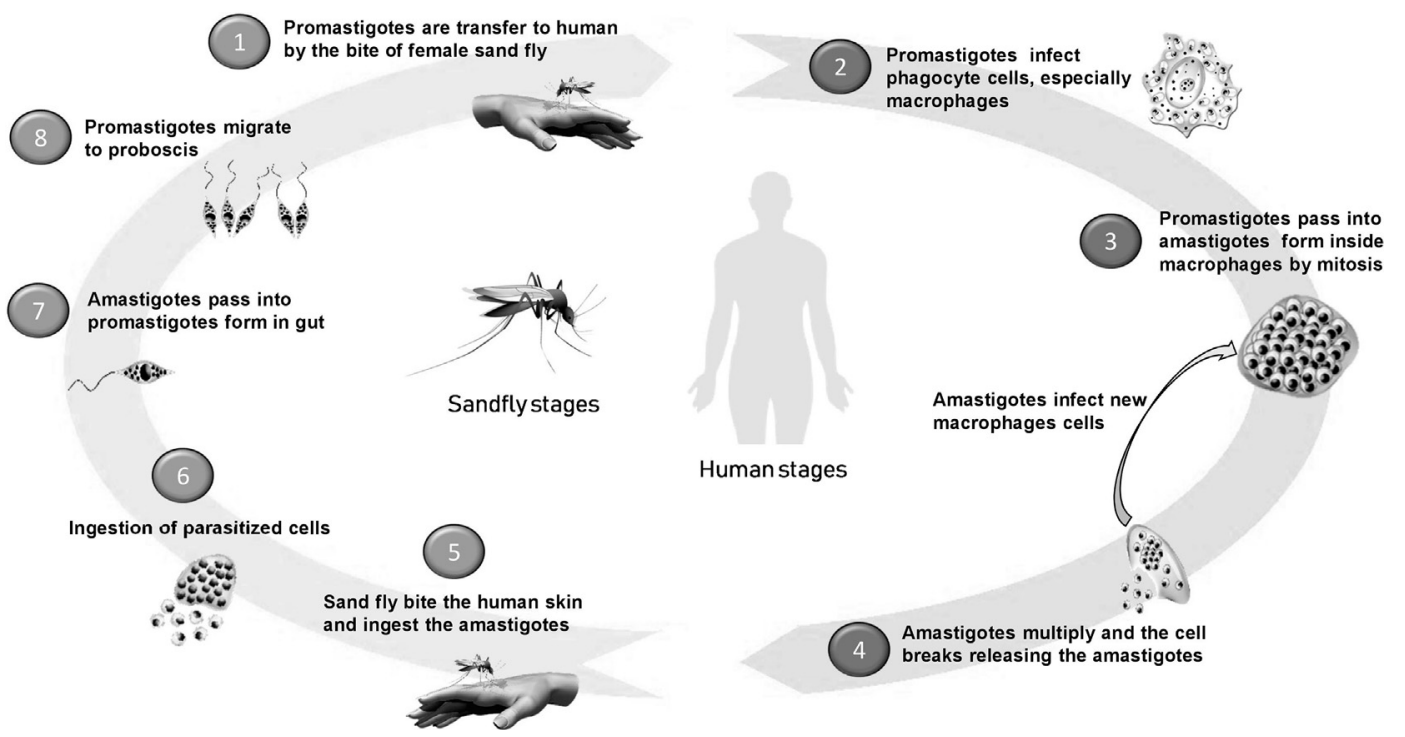

Fig. 1. Cycle of life of Leishmaniasis parasite.

endemic for CL and 75 for VL. Southeast Asia is the most affected by VL (9250) followed by Africa (5796) and eastern Mediterranean (4501). For CL, the eastern Mediterranean is the most affected $(139,033)$ followed by the Americas $(46,304)$ and Africa (7984) (World Health Organization/Department of Control of Neglected Tropical Diseases, 2017).

According to the WHO, in 2015, 25 countries were considered a high-burden for leishmaniasis, which means they present over 100 cases of VL and over 2500 cases of CL. Of these, 13 countries show highburden of VL and 11, high burden of CL. Brazil is the only country to present high burden for both forms of Leishmaniasis (World Health Organization, 2016b).

Considering the total number of cases of CL in the Americas, 70\% were reported by Peru (5459), Colombia (7541), and Brazil $(19,395)$. In the Americas, $69 \%$ of the cases of CL affect males and $12.7 \%$ occur in those younger than 10 years old. Secondary infection is reported in $54.2 \%$ of cases and is usually caused by Staphylococcus aureus (Ekiz et al., 2017). Another important reported coinfection was CL/human immunodeficiency virus (HIV), which is present in 198 of the cases $(0.43 \%)$, of which 135 were reported in Brazil and 63 cases in Colombia (Pan American Health Organization, 2017).

According to the Pan American Health Organization (PAHO), in 2015, among the 12 countries affected in the Americas by VL, $96 \%$ of the cases were reported in Brazil (3289), with 268 deaths and a fatality rate of $7.7 \%$. Of the total number of described cases, $64.64 \%$ (2234) were men and $31.9 \%$ were children under five years old. For Venezuela, Honduras and Colombia, the infected children represent 59.5\%, 83.3\% and $95.2 \%$, respectively. In this same year, 257 (7.4\%) of VL/HIV coinfection cases were registered, including a single case in Venezuela, 12 in Paraguay and 244 of which were reported in Brazil (Pan American Health Organization, 2017).

In Brazil the Northeast region is the most affect by VL, but the numbers have decreased from 2022 in 2014 to 1523 in 2016, a reduction of approximately $25 \%$. Due to this decrease, the total number reported by Brazil also decreased in 2016 (3200). However, all the other regions reported an increase of VL cases (Ministério da Saúde, 2017a) although the fatality rate decreased in 2015 (6.6\%) compared to 2014 (7.8\%) (Ministério da Saúde, 2017b). Despite these figures, the southern region of Brazil, comprising three of the ten wealthiest states, showed an increase of $40 \%$ in the fatality rate (Ministério da Saúde, 2017c). For CL, Brazil showed a decrease in all regions in 2016 (Ministério da Saúde, 2017d).

Chemotherapy is the main means of treating this infection.
Nevertheless, only a few effective drugs are available and each one has a particular disadvantage and toxicity (Pham et al., 2013); long-term regimens compromise most chemotherapeutic options. Thus, the search for safer, more efficient, innovative, cost-effective therapies is urgently needed for treating leishmaniasis.

During the last decade, nanotechnology drug delivery systems (NanoDDS) have been used to enhance the performance of drugs in treating several diseases. Different nanotherapeutics have been approved by the FDA and are currently available for clinical use (Eifler and Thaxton, 2011). Therefore, this review is an effort to comprehensively compile the findings of recent studies while underscoring the importance of nanotechnology for treating leishmaniasis.

\section{Leishmaniasis infection}

VL, CL and MCL are infections caused by intracellular protozoans in humans by 20 different species of Leishmania (World Health Organization, 2017) among more than 53 species (Akhoundi et al., 2016).

The transmission occurs through the bite of female phlebotomine sandflies (98 of 800 species infect humans) (Akhoundi et al., 2016; World Health Organization, 2016b). The Old World is affected by the sandfly of the genus Phlebotomus (Kevric et al., 2015) and the New World by Lutzomyia (Borghi et al., 2017). Moreover, leishmaniasis can be classified as anthroponotic or zoonotic, the natural reservoir is human or animal, respectively (World Health Organization, 2016b).

The parasites have two life-cycles (Fig. 1): an extracellular mobile stage (promastigote) exclusive to an invertebrate host and an intracellular (amastigote) non-mobile stage in a mammalian vertebrate host (Borghi et al., 2017). In vertebrates, Leishmania parasites infect phagocyte cells, especially macrophages, which are considered to be the major cellular compartments for Leishmania in the mammalian vertebrate host (Kobets et al., 2012). Promastigotes form, after infecting cells of the mononuclear phagocytic system, passing into the amastigote form and begin to multiply. Multiplication leads to rupture of the host cell releasing parasites, which infect other macrophages (Borghi et al., 2017).

VL is generally caused by the Leishmania donovani complex, which includes the species Leishmania infantum, Leishmania chagasi, and Leishmania donovani (De Carvalho et al., 2013; Soares-bezerra et al., 2004) CL and MCL forms are caused by several Leishmania species, including Leishmania tropica, Leishmania major, Leishmania amazonensis (CL) and Leishmania braziliensis (Minodier and Parola, 2007). The lag 
period between developing cutaneous and mucosal lesions ranges from months to years (Ekiz et al., 2017).

The cause of the appearance of mucocutaneous form can be associated with the species of parasite, and with the immunity of the host and the site of the primary lesion (Crovetto-Martínez et al., 2015). The MCL is the result of those species that can be disseminated by haematogenous or lymphatic system through the mucosal tissues of the mouth and/or upper respiratory tract (Strazzulla et al., 2013). Immunosuppressed patients can present similar conditions with different Leishmania species. Lesions above the waist, various or extensive primary lesions or delayed healing of primary CL can be also a risk factor (WHO technical report series 949, 2010).

\section{Overview of current chemotherapy}

Historically, pentavalent antimonials (30 days, $20 \mathrm{mg} / \mathrm{kg} /$ day) are the gold standard for treating leishmaniasis (Palumbo, 2010), which have been dispensed parenteral as first-line chemotherapy against all forms of leishmaniasis and still the drug of first choice for treatment (Pham et al., 2013). The two pentavalent antimonials available, sodium stibogluconate (Pentostan ${ }^{\circledast}$ ) and meglumine antimoniate (Glucantime $^{\circledast}$ ), are not ideal due to their toxicity and the requirement of hospitalization for the administration (Palumbo, 2010). The adverse effects of the drug include pancreatitis, cardiotoxicity, nephrotoxicity, hepatotoxicity (WHO technical report series 949, 2010), which decreases patient compliance and adherence to the treatment and consequently the emergence of drug-resistant strains (Jebali and Kazemi, 2013).

Second-line recommended treatment consists of amphotericin B (AMB) deoxycholate (Fungizone ${ }^{\circledast}, 30$ days with $1 \mathrm{mg} / \mathrm{kg}$ ), liposomal amphotericin B (AmBisome ${ }^{\circledR}$, single-dose $10 \mathrm{mg} / \mathrm{Kg}$ ), pentamidine (Pentam ${ }^{\circledR}$, 3-5 days with $4 \mathrm{mg} / \mathrm{kg}$ ), miltefosine (MILT) (Impavido ${ }^{\circledR}$, 28 days with $1.5-2.5 \mathrm{mg} /$ day) and paromomycin (PRM) (Humatin ${ }^{\circledR}$, 21 days with $15 \mathrm{mg} / \mathrm{kg} /$ day). These drug substances can be used as combined therapy, which would increase efficacy and tolerance, reducing cost of the treatment and limit drug resistance (Mcgwire and Satoskar, 2014; Pham et al., 2013; WHO technical report series 949, 2010).

\section{Recent advances in treating leishmaniasis: impact of nanotechnology}

Among the new molecules, including those for the treatment of leishmaniasis approved for the development of new drugs, $40 \%$ presents low aqueous solubility. Additionally, considering those in the discovery pipeline, this figure raises to 90\% (Kalepu and Nekkanti, 2015). NanoDDS is an alternative and promising approach that allows improving the solubility characteristics of class II and IV drugs of the Biopharmaceutical Classification System. The solubility of the drug in aqueous medium is determinant for its therapeutic efficacy (SaffieSiebert et al., 2005; Sharma et al., 2016).

Furthermore, the use of NanoDDS can increase therapeutic efficacy by releasing leishmanicidal drug substances in macrophage-rich organs such as bone marrow, liver, and spleen. This strategy takes advantage of a particulate matter uptake mechanism by macrophages, which is the main phagocytic cell involved in leishmaniasis infection. These cells express receptors that efficiently internalize nanoparticles (NPs) in the range of 50-500 nm (Siefert et al., 2016). Phagocytosis, which allows nanoparticles to be engulfed, can increase intracellular drug concentration and a modified drug release can be achieved (Coelho et al., 2014).

Thus, NanoDDS can direct antileishmanial drug substances for intracellular localization in its site of action, improving the efficacy and decreasing the toxic effects of these drugs (Gupta et al., 2010; Salouti and Ahangari, 2014). In the last decade, several studies have proposed applying NanoDDS for treating leishmaniasis (Kalangi et al., 2016) using metallic, lipid, polymeric nanoparticles, liposome and nanocrystal.

In this review, the cutaneous leishmaniasis was targeted in $45.2 \%$ (14 of 31 ) of the studies, against $41.9 \%$ for visceral leishmaniasis. The others $12.9 \%$ ( 4 of 31 ) of the studies did not determine the target of the formulation. Among the nanostructures, the metallic nanoparticles were mostly tested for cutaneous leishmaniasis (73.3\%), while the lipid and polymeric nanoparticles were most tested for visceral leishmaniasis $(62.5 \%)$.

\subsection{The role of metallic and metal oxide nanoparticle}

In recent years, metallic nanoparticles have been a focus of interest because of their potential in theranostic nanomedicine (Mody et al., 2010; Xie et al., 2010). Several chemical, physical and biological synthetic methods have been proposed in designing these nanoparticles (Iravani, 2011). Among these, the green synthesis method stands out, which is an ecofriendly and solvent-free approach (Arokiyaraj et al., 2016; Iravani, 2011).

Considering the literature, several authors have reported the potential of inorganic nanoparticles against leishmanicidal activity when tested in vivo. Beheshti and collaborators (2013) reported that selenium nanoparticles (SeNPs) can inhibit the proliferation of the amastigote and promastigote forms of Leishmania major and limited the growth of $\mathrm{CL}$ in animal model. These nanoparticles were biosynthesized via $\mathrm{Ba}$ cillus $s p$ as described by Shakibaie et al. (2010). Also it was possible to eliminate cutaneous lesions in infected BALB/c mice when SeNPs were administered after developing cutaneous lesions (Beheshti et al., 2013).

Silver nanoparticles (AgNPs) showed antimicrobial, antifungal, and antiviral properties (Chaloupka et al., 2010). Since 2009, AgNPs have been studied for treating and enhancing drug substance delivery against leishmaniasis (Mohebali et al., 2009), showing to be a highly effective trypanothione reductase inhibitor in Leishmania donovani (Baiocco et al., 2011) infection. Complimentary investigations have demonstrated that it is possible to reduce the inhibitory concentration of miltefosine by half using AgNPs in synergy against Leishmania parasites. Kalangi et al. (2016) reported a green synthesis of AgNPs using dill leaf extract. The synergism of AgNPs associated with miltefosine was demonstrated by a decrease in $\mathrm{IC}_{50}$ and increase (2-fold) in leishmanicidal activity (Kalangi et al., 2016).

Additionally, Allahverdiyev and collaborators (2011) reported the antileishmanial activity of AgNPs in the presence of ultraviolet (UV) light on amastigotes and promastigotes of Leishmania tropica. The findings indicated a significant decrease in antileishmanial activity by AgNPs. The proliferation and metabolic activity of the parasite in promastigotes was reduced by 1.5 to 3 -fold, respectively, in the dark, and 2 to 6.5-fold, respectively, under UV light. Also, inhibition of amastigotes in host cells was most significant in the presence of UV light (Allahverdiyev et al., 2011). Given this, Mayelifar and coworkers (2015) showed the influence of a low dose ultraviolet B (UVB) radiation along with AgNPs in treating CL. These findings demonstrated the excellent pronounced inhibitory effect in the group that received AgNPs and phototherapy UVB. The results indicated synergism of UVB radiation with a cumulative dose of $150 \mathrm{~mJ} / \mathrm{cm}^{2}$ with AgNPs at a concentration of $2 \mathrm{mg} / \mathrm{kg}$. AgNPs, UVB radiation or combined treatment were able to inhibit the growth of the cutaneous lesions and control infection (Mayelifar et al., 2015).

The use of nanoparticles under UV and infrared (IR) light have high toxicity by generating reactive oxygen species (ROS) causing the death of the organism. Jebali and Kazemi (2013) evaluated antileishmanial effects of some nanoparticles with AgNPs, AuNPs, $\mathrm{TiO}_{2} \mathrm{NPs}$, ZnONPs and MgONPs on Leishmania major parasites under UV, IR, and dark conditions. In this study, increased antileishmanial activity was observed for AgNPs, followed by AuNPs, $\mathrm{TiO}_{2} \mathrm{NPs}$, ZnONPs, and MgONPs. Thus, both UV and IR light improved antileishmanial properties of these nanoparticles, which must be considered in future studies (Jebali and 
Table 1

Metallic and metal oxide nanoparticle delivery systems for treating leishmaniasis.

\begin{tabular}{|c|c|c|c|c|}
\hline Drug/active substance & Ref. & Size (nm) & $\mathrm{IC}_{50}$ & Method of preparation \\
\hline Selenium & Beheshti et al. (2013) & $80-220$ & $\begin{array}{l}1.62 \pm 0.6 \mu \mathrm{g} / \mathrm{mL} \text { promastigote } \\
4.4 \pm 0.6 \mu \mathrm{g} / \mathrm{mL} \text { amastigote }\end{array}$ & biosynthesized via Bacillus sp. \\
\hline $\begin{array}{l}\text { Silver } \\
\text { Miltefosine }\end{array}$ & Kalangi et al. (2016) & 35 & $12.5 \mu \mathrm{M}$ MILT $+50 \mu \mathrm{M}$ AgNP promastigote & green synthesis \\
\hline Quercetin & Das et al. (2013) & 15.07 & $\begin{array}{l}15 \pm 3 \mu \mathrm{M} \text { wild type } \\
40 \pm 8 \mu \mathrm{M} \text { sodium stibogluconate resistant strain }\end{array}$ & green synthesis \\
\hline Gold & & & $30 \pm 6 \mu \mathrm{M}$ paromomycin-resistant strains & \\
\hline Zinc & Delavari et al. (2014) & 20 & $37.8 \mu \mathrm{g} / \mathrm{ml}$ promastigote & from Selekchem Company, USA \\
\hline Silver & Zahir et al. (2015) & $\begin{array}{l}12.82 \pm 2.50 \\
83.22 \pm 1.50\end{array}$ & $\begin{array}{l}14.94 \mu \mathrm{g} / \mathrm{mL} \text { promastigote } \\
3.89 \mu \mathrm{g} / \mathrm{mL} \text { amastigote }\end{array}$ & green synthesis \\
\hline
\end{tabular}

Ref.: reference; $\mathrm{IC}_{50}: 50 \%$ inhibitory concentrations; MILT: miltefosine; AgNP: silver nanoparticles.

Kazemi, 2013).

Allahverdiyev et al. (2013) observed the leishmanicidal effect of titanium dioxide and silver nanoparticles (TiAgNps) on the biological properties of Leishmania infantum and Leishmania tropica parasites. The study aimed to compare their metabolic activity, survival, and viability within host cells both in the presence of dark and UV light. The findings show that TiAgNps reduced viability rates of Leishmania infantum and Leishmania tropica promastigotes by 10 and 3-fold, respectively, in the dark, although these values decreased closely 20 -fold for each species using UV light, in contrast to control (Allahverdiyev et al., 2013).

As alternative, metallic nanoparticles have been combined with bioactive compounds improving antileishmanial activity. Das et al. (2013) developed and evaluated gold nanoparticles conjugated with quercetin (QAuNP) against leishmanial macrophage infection. Macrophage uptake of gold nanoparticles and antileishmanial activity were studied against both the wild- and resistant-type parasites. The authors revealed antileishmanial activity of QAuNP against drug resistant strains with a high selectivity index (Das et al., 2013).

In a recent study, Abamor and Allahverdiyev (2016) proposed to investigate antileishmanial activity of TiAgNps, in vitro, in combination with essential oils of Nigella sativa obtained by different extraction methods. Its major constituent, thymoquinone, showed inhibitory effects on Leishmania infantum and Leishmania tropica parasites. An enhanced inhibitory effect of the combined agents on Leishmania tropica promastigotes (1.5-25 folds) and amastigotes (5-20 folds) was observed in contrast when the substances were used alone, while decreasing their toxicity to minimal levels. The presence of synergism was attributed to different action mechanisms of investigated agents (Abamor and Allahverdiyev, 2016).

In addition to metallic, metal oxide nanoparticles have shown to be a promising approach as an alternative to antibiotics in treating infectious diseases, interacting with vital mechanisms of infectious agents, such as DNA and enzymes, and disrupting their components (Panáček et al., 2006).

Bafghi and coworkers (2015) showed the activity of magnesium oxide nanoparticles (MgONPs) and MgONPs coated with glucose (MONPCG) on Leshmania major. The authors evaluated cell viability and expression of two genes (GP63 and $\mathrm{Cpb}$ ) after incubation with MgONPs and MONPCG. Thus, the expression of these genes was reduced with an increase of nanoparticle concentration. Consequently, the increase of incubation time led to reduction of their expression in MgONPs treated promastigotes; however, a reduction was not observed in MONPCG treated promastigotes (Bafghi et al., 2015).

Delavari et al. (2014) evaluated in vitro antileishmanial activity of zinc oxide nanoparticles (ZnONPs). ZnONPs showed dose dependent antileishmanial activity by induced apoptosis in Leishmania major (Delavari et al., 2014).

Zahir and collaborators (2015) proposed synthesizing AgNPs and titanium dioxide $\left(\mathrm{TiO}_{2}\right)$ nanoparticles using aqueous leaf extract of Euphorbia prostrata, which present antileishmanial activity. Comparing the metallic (AgNP) and metal oxide nanoparticles (AgONP), it was found that AgNPs were the most active against Leishmania parasites after $24 \mathrm{~h}$ exposure when it was evaluated in vitro antileishmanial activity. The authors also showed the unique trypanothione/trypanothione reductase system of Leishmania cells, which was expressively inhibited by synthesized AgNPs. Thus, these AgNPs presented promising leads for developing cost-effective and safer alternative treatment against VL (Zahir et al., 2015).

Metal oxide and metallic nanoparticles are widely used in various applications and usually classified as non-toxic due to the absence of toxicity of the bulk material. Nevertheless, these nanoparticles (NPs) naturally have toxicity to bacteria and fungi (Djurišić et al., 2015). Toxicities associated with NPs in infectious agents are usually related to their causing damage such as generating ROS and oxidative DNA damage (Niazi and Gu, 2009). Additionally, NPs can be potentially dangerous to the central nervous system in some properties, such as lysosome dysfunction, autophagy, oxidative stress, and the activation of certain signaling pathways (Wei et al., 2015).

Consensus on toxicity mechanisms remains inconclusive, with different studies demonstrating contradictory findings. The relation between the NP mechanisms and toxicity is complex and difficult to understand, demonstrating that there is need for further research in this area. Table 1 shows the metallic nanoparticles for treating leishmaniasis.

Metallic and metal oxide nanoparticles have potential to be developed for treating leishmaniasis, as shown in Table 1.

\subsection{Liposome: challenges and opportunities}

Despite being invented over 50 years ago, there are only 15 liposome formulations on the market, mainly for anticancer therapy (Bulbake et al., 2017). Since the 1970s, the efficacy of intravenous administration of liposomal formulations has improved together with a better understanding of the liposomal structure (Lopes et al., 2012). Liposomes are small artificial vesicles $(80 \mathrm{~nm}$ to $100 \mu \mathrm{m})$ consisting of concentric spheres of lipid bilayers created from cholesterol and phospholipids. The most common method used for liposome preparation is the thin-film hydration procedure (Sharma and Sharma, 1997). The lipids are dissolved in organic solvent, such as trichloromethane (Cui et al., 2015), chloroform (Soema et al., 2015) and a dry lipid film is then formed when the solvent evaporates (Bangham et al., 1965). The next step is to hydrate the film with an aqueous solution, such as a buffer solution $\mathrm{pH}$ 7-7.4, using a temperature higher than the lipid transition temperature (Sharma and Sharma, 1997).

Alterations in the pharmacokinetic and biodistribution profiles and/ or in establishing a modified release of the drug due to association with these carrier systems lead to improvements in the pharmacological and therapeutic properties of the drugs. After in vivo administration and depending on their physicochemical properties, liposomes are perceived as external materials being cleared by cells of the mononuclear phagocytic system (Kelly et al., 2011), which are infected by parasites in leishmaniasis. Thus, the accumulation of antimicrobial drug 
substances through their combination with liposomes can deliver relevant benefits to the therapy (Gaspar et al., 2008a,b).

The liposomal AMB (L-AMB) (AmBisome ${ }^{\circledR}$ ), used for the treatment of systemic fungal infections, has become a standard treatment for VL (Van de Ven et al., 2012) and a second line treatment for CL. New et al. (1981) first reported L-AMB efficacy against leishmaniasis in 1981. Only almost two decades after this first study, in 1997, the FDA approved this product for treating this disease (Vyas and Gupta, 2006).

L-AMB is composed of high transition temperature phospholipids and cholesterol, designed to incorporate AMB securely into the liposomal bilayer. The AMB, after being released from the liposomes, is thought to transfer through the cell wall and bind to ergosterol in the parasite of Leishmania cell membrane. Hence, AMB forms aqueous pores within the plasma membrane and increase the permeability to monovalent cations and small metabolites (Saha et al., 1986; Ramos et al., 1996). AMB also showed to have affinity to cholesterol of host macrophages cells (Mouri et al., 2008; Readio and Bittman, 1982), that is required to bind and internalize the parasite into macrophages (Pucadyil et al., 2004). AMB sequester cholesterol from host macrophages cells and inhibit the infection of Leishmania (Paila et al., 2010). More recently, Chattopadhyay and Jafurulla (2011) proposed a novel AMB leishmanicidal mechanism, which included a combination of the interaction with ergosterol of Leishmania and the cholesterol of host macrophages.

The pharmacokinetics studies of L-AMB were performed in immunosuppressed patients with fungal infections. It has never been conducted in leishmaniasis patients (Kip et al., 2018) Pharmacokinetics studies revealed a statistically significant relationship between mean area under curve (AUC) and probability of nephrotoxicity and a nonlinear pharmacokinetics (Lestner et al. 2016). Seibel et al. (2017) showed that all immunosuppressed children (40), but three, had side effects after administration of L-AMB. The patients that received $10 \mathrm{mg} /$ $\mathrm{kg}$ of L-AMB presented more side effects than those who received $2.5 \mathrm{mg} / \mathrm{kg}$. The study also showed a non-linear pharmacokinetics. Patients treated with $0.6 \mathrm{mg} / \mathrm{kg}$ of AMB $(0.060 \pm 0.01 \mu \mathrm{g} / \mathrm{mL})$ presented significantly higher Cmax (mean $\pm \mathrm{SD}$ ) than patients treated with $2 \mathrm{mg} / \mathrm{kg}$ of L-AMB $(0.016 \pm 0.004 \mu \mathrm{g} / \mathrm{mL})$ allowing reducing the side effects of AMB (Bekersky et al., 2002). For leishmaniases, Wijnant et al. (2017) compared the skin pharmacokinetics of L-AMB with AMB, in murine models of Leishmania major. The study showed that after multiple administration, on day 10, the drug level in the lesion location was 3 -fold higher for L-AMB than for AMB. The study also showed the linear correlation between dose level, intralesional AMB concentration and relative reduction in parasite load and lesion size.

However, the use of L-AMB continues to be restricted due to a major drawback; its repeated administration results in accumulation due to slow elimination from the body, finally directing to nephrotoxicity, in addition to its high cost (Costa Lima et al., 2014). For a patient weighing $35 \mathrm{~kg}$, L-AMB costs US\$ 126 for a daily treatment $(10 \mathrm{mg} / \mathrm{kg})$, which means a 6.3-fold higher cost for AMB (30-day treatment, $1 \mathrm{mg}$ / $\mathrm{kg}$, alternating days) (WHO, 2010). However, Sundar et al. (2010) showed that a single-dose regimen of L-AMB $(10 \mathrm{mg} / \mathrm{Kg})$ is effective, noninferior and less expensive to treatment with AMB deoxycholate (15 alternate-day infusions of $1 \mathrm{mg} / \mathrm{Kg}$ during a 30-day hospital stay).

Several liposomal formulations have been described as an alternative to AmBisome ${ }^{\circledast}$. Paromomycin (PRM) delivered by liposomes exposed preferential targeting of the antibiotic to the spleen, lungs and liver, relative to free PRM, which resulted in improved therapeutic efficacy and lower toxic effects in murine models infected with Mycobacterium avium and Leishmania infantum (Gaspar et al., 2015). Additionally, liposomal trifluralin (L-TFL) showed decrease in parasite loads in a murine visceral model of infection by Leishmania donovani (Carvalheiro et al., 2009).

Later, the same authors, Carvalheiro and coworkers (2015), developed trifluralin analogues liposomes, TFL-A3 and TFL-A6, to further enhance TFL antileishmanial activity. The efficacy of the liposomal formulations TFL-A3 and TFL-A6 were assessed in vitro against Leishmania infantum resulting in $\mathrm{IC}_{50} 1.2 \pm 0.4 \mu \mathrm{M}$ and $\mathrm{IC}_{50} 1.8 \pm 1.3 \mu \mathrm{M}$, respectively, and in vivo in a murine model of zoonotic visceral leishmaniasis. Furthermore, the findings reported trifluralin analogues were capable to target the intracellular amastigote form of Leishmania infantum in infected macrophages revealing the therapeutic activity of liposomal formulations (Carvalheiro et al., 2015).

\subsection{The scope of lipid nanoparticle}

Lipid colloidal drug carriers such as nanoemulsions (NE), solid lipid nanoparticle (SLN) and nanostructured lipid carrier (NLC) have been of great interest to drug delivery scientists mainly due to their versatile nature and interesting advantages as administration of poor water-soluble drug (Date et al., 2007). These include a higher degree of safety, mainly biocompatibility and biodegradability, and the efficacy comprising their feasibility to be tailored for a wide range of formulations according to the route of administration or disease (Attama et al., 2012; Yukuyama et al., 2017a).

These carriers have the potential to enable oral administration of antileishmanial drugs targeting the lymphatic system. Leishmaniasis disseminates through the lymphatic and vascular systems and infects monocytes and macrophages in liver, spleen, bone marrow and lymph nodes. Charman and Stella (1986) found that the solubility of the drug in triglycerides ( $>50 \mathrm{mg} / \mathrm{mL}$ ), and the octanol:water partition coefficient $(\log \mathrm{P}>5$ ) contributes to improve its absorption to lymphatic system. Later, Paliwal et al. (2009) and Caliph et al. (2000) showed that triglycerides with long chain are better transported to lymphatic system than the medium chain ones. Furthermore, Ibrahim et al. (2013) demonstrated the influence of the type and ratio of lipids in the pharmacokinetic of AMB after oral administration. This study showed that lipid-based formulation could point to higher steady state concentrations in the tissues after multiple doses, which can improve the destruction of leishmanial parasites. Recent advances in lipid-based nano formulations corroborated these findings. The lymphatic uptake and oral bioavailability of curcumin-SLN coated with N-carboxymethyl chitosan were 6.3-fold and 9.5-fold higher than that of free curcumin, respectively. These results suggest that SLN could be an efficient oral delivery system for curcumin (Baek and Cho, 2017). Additionally, after oral administration in rats, topotecan (TPT), a water-soluble chemotherapeutic agent lipid nanoparticle allowed to enhance the intestinal lymphatic transport of TPT (Wang et al., 2017).

NEs are a colloidal particulate system, being submicron in size, with varying roles as carriers of drug substances. Their size ranges from 10 to $1000 \mathrm{~nm}$ (Jaiswal et al., 2015) and the main components are lipid liquid, surfactant and aqueous phase (Gasco et al., 1991). These components form a dispersion of two immiscible phases, which are kinetically stable and thermodynamically unstable. Under the selected surfactant type, they can be presented as oil-in-water $(\mathrm{O} / \mathrm{W})$ or waterin-oil (W/O) NE, or even generate a cationic or anionic NE (Fryd and Mason, 2012; Rodriguez-Aller et al., 2015).

The SLN exchanges the liquid lipid of the emulsions by a solid lipid, which results in lipids being solid at room and body temperature. The mean diameter of the NLS ranges from 40 to $1000 \mathrm{~nm}$ (Müller et al., 2002; Weber et al., 2014). The NLC, the second generation of lipid nanoparticles, are composed of colloidal particles that present a matrix composed of a binary mixture of solid lipid with liquid lipid providing a less ordered structure but still solid in body temperature (Poonia et al., 2016).

Two main processes are required for obtaining NE, SLN and NLC: high- and low-energy methods. The first one, driven by mechanical force, comprises high-pressure homogenization, ultrasound and microfluidization. They involve mainly shearing, collision, and cavitational force for breaking down the droplets into a nanoscale range (Attama et al., 2012; Date et al., 2007; Yukuyama et al., 2017b). The second one is driven by the physicochemical energy, which consists of 
the spontaneous curvature change of the phases to break down the particles to deliver the final nanodroplets, during the phase transition process. The low-energy process includes the phase inversion temperature and composition methods (PIT and PIC), spontaneous emulsification (Anton et al., 2008; Koroleva and Yurtov, 2012; Yukuyama et al., 2016) and the D-Phase emulsification method (Sagitani et al., 1991). Naseri et al. (2015) describe two other techniques for preparing SLN and NLC, solvent emulsification /evaporation and supercritical fluid extraction of emulsions (SFEE), both techniques use organic solvent to prepare the nanoparticles and each one uses different approaches to remove the solvents.

Koester and collaborators (2015) successfully incorporated chalcone in nanoemulsions for topical administration in treating CL. This nanoemulsion improved activity against intracellular amastigotes of $L$. amazonensis in THP-1 cells. Additionally, considering the parasitic inhibition profile, this formulation demonstrated both stability and maintenance of leishmanicidal activity (Koester et al., 2015).

Lopes et al. (2012) proposed the encapsulated oryzalin containing dinitroanilines in SLN for parenteral administration. The formulation showed encapsulation efficiency $>75 \%$ without cytotoxicity effect for all concentrations tested indicating a very protective role to mammalian cells. Thus, suggesting that this strategy may improve the tolerability and therapeutic range of dinitroanilines.

Pham and coworkers (2014) proposed an SLN based on nanocochleates. These are stable cationic phospholipid precipitates with multilayered cylindrical structures, composed of positively charged calcium ions and negatively charged phospholipids (Nagarsekar et al., 2016) combining two drug substances: AMB and MILT, which could be administered by the oral route. After nanocochleate preparation, the encapsulation efficiency was 54\% and 59\% for AMB and MILT, respectively. Drug release is present preferentially in intestinal medium containing bile salts. The release rate of MILT was slightly higher than that of AMB, probably because of the amphiphilic mechanisms of the former. Therefore, AMB-MILT-loaded nanocochleates revealed to be a promising oral delivery system for VL therapy (Pham et al., 2014).

Jung and collaborators (2009) prepared the SLN which can entrap poor water-soluble drugs, AMB, with high drug entrapment efficiency by using solvent evaporation (SESE) and spontaneous emulsification low energy method. Entrapment efficiency of AMB in the SLN reached up to $76.5 \pm 5 \%$. The cytotoxicity of AMB-entrapping SLN against normal kidney cells (293 cells) presented to be lower compared with those of the commercial AMB-products, Fungizone ${ }^{\circledast}$ and AmBisome ${ }^{\circledast}$.

Kharaji and coworkers (2015) have reported PRM-SLN formulation containing $15 \%$ lipid composition, which showed efficacy in parasite inhibition. In another study, the authors (Heidari-Kharaji et al., 2016) reported the PRM-SLN formulation as a novel drug delivery for treating leishmaniasis. The preparation was safe and inhibited the propagation of $L$. major parasites in infected mice. Thus, the authors have successfully demonstrated acceptable efficacy and safety of the PRM-SLN formulation as a novel drug against CL. PRM-loaded SLN may increase drug penetration into macrophages and efficient uptake by macrophages may explain the higher efficacy of this treatment (HeidariKharaji et al., 2016).

Buparvaquone application in leishmaniasis therapy has been limited by its poor-water solubility. Aiming to overcome this disadvantage, Monteiro et al. (2017a) first described a successful preparation of NLC containing buparvaquone. This drug delivery system has the potential to improve the availability of affordable therapy due to the low cost of raw materials and the use of high-pressure homogenization, a scale-up feasible technology (Monteiro et al., 2017a).

NLCs have been proposed for treating various neglected diseases such as malaria (Omwoyo et al., 2016; Parashar et al., 2016), Chagas disease (Morilla and Romero, 2015; Vargas de Oliveira et al., 2017), schistosomiasis (Kolenyak-Santos et al., 2015), dengue fever (Tsai et al., 2012) and tuberculosis (Beg et al., 2017). However, this platform has been still poorly explored for treating leishmaniasis, as shown in
Table 2.

\subsection{Polymeric nanoparticle: synthetic and natural matrices}

Polymeric nanoparticles are solid colloidal particles, with size of less than $1 \mu \mathrm{m}$, made of various biocompatible polymeric matrices (Date et al., 2007). The drug may be dissolved, retained or adsorbed in the polymer matrix, or in the case of nanocapsules, solubilized in the oily nucleus (Dimer et al., 2013). Polymeric particles have capacity to impact specific drug release kinetic patterns and increase biocompatibility. Biodegradable polymers include synthetic polymers such as polyalkylcyanoacrylates (PACA), poly (lactic acid) (PLA), poly (n-butyl cyanoacrylate) (PBCA), poly (lactide-co-glycolide) (PLGA), poly (caprolactone) (PCL), poly (glycolic acid) (PGA), poly (amino acids) and natural polymers such as gelatin, albumin, chitosan, and alginate (Banik et al., 2016).

Different methods have been employed to load antileishmanial drug substances into polymeric nanoparticles such as emulsion or microemulsion polymerization (Monteiro et al., 2017b), interfacial polymerization (Chaubey and Mishra, 2014) and precipitation polymerization (Kumar et al., 2015). Their major drawbacks refer to inadequate biodegradability and/or the possible presence of organic solvent toxic residues (Ahlin Grabnar and Kristl, 2011). The removal of solvent represents a time-consuming procedure and any residue can pose a risk to the patient.

Despite a diverse number of polymer molecular structures, most of them (probably $>95 \%$ ) are not suitable for clinical use. Different weight, architecture and the specific linking chemistry used during the polymer conjugation can impact in safety and efficacy. The discussion of an appropriate regulatory framework has become fundamental (Duncan, 2011). Gaspar and Duncan (2009) described the challenges of the regulatory agencies and the importance to treat each polymer used in therapeutic as unique, based on route of administration, doses, dosing frequency and proposal clinical use.

De Carvalho et al. (2013) developed AMB nanoencapsulated in PLGA and dimercaptosuccinic acid (DMSA) nanoparticles (Nano-DAMB). Its efficacy was evaluated in treating CL. Because hyperthermia based on magnetic nanoparticles results in controlled release of the drug (De Carvalho et al., 2013; Kumar and Mohammad, 2011), magnetic citrate-coated nanoparticles (Nano-D-AMB-MG) were combined in this nanosystem, in an attempt to improve the release of $\mathrm{AMB}$ by magneto hyperthermia. Although Nano-D-AMB-MG showed the same potential as free D-AMB in reducing cutaneous leishmaniasis lesions, the Nano-D-AMB-MG treatment promoted significantly greater reductions in the number of parasites and in cell viability than free D-AMB. This suggests that these NPs were more efficacious than free D-AMB therapy, allowing the dose frequency required to reach the same therapeutic level to be reduced, and thus favoring an extended dosing interval (De Carvalho et al., 2013).

Rifampicin (RIF) is well-known and described as an antituberculosis drug; its antileishmanial activity has been reported (Neuber, 2008). Chaubey and Mishra (2014) developed a novel RIF-loaded mannoseconjugated chitosan nanoparticulate system targeting macrophages for treating visceral leishmaniasis. This targeted delivery system was efficient, viable, safe and affordable. Ex vivo pharmacokinetic and biodistribution studies resulted in an expressive increased concentration of RIF in liver and spleen. The cellular drug uptake was 16.2 times higher than that of the free drug (Chaubey and Mishra, 2014).

Kumar et al. (2015) developed PLGA-PEG encapsulated AMB nanoparticles to target the macrophage of visceral leishmaniasis infected tissues. This system showed cytotoxicity of extracellular promastigote 1.4-fold lower than free AMB. In addition, amastigote inhibition in the splenic tissue was expressively higher than with conventional AMB (93.02 $\pm 6.63 \%$ versus $74.42 \pm 14.78 \%)$. Thus, AMB encapsulated PLGA-PEG NPs showed to have greater potential than free AMB in terms of therapeutic efficacy in in vitro and in vivo studies (Kumar et al., 
Table 2

Lipid matrix nanoparticle delivery systems for treating leishmaniasis.

\begin{tabular}{|c|c|c|c|c|c|c|c|c|}
\hline $\begin{array}{l}\text { Drug/active } \\
\text { substance }\end{array}$ & Ref. & Size (nm) & PDI & Zeta Potential (mV) & $\mathrm{EE} \%$ & Lipid & $\begin{array}{l}\text { Class } \\
\text { component }\end{array}$ & $\begin{array}{l}\text { Method of } \\
\text { preparation }\end{array}$ \\
\hline Paromomycin & $\begin{array}{l}\text { Gaspar et al. } \\
\text { (2015) }\end{array}$ & 110 & $<0.1$ & $-30 \pm 2$ & $96 \pm 4$ & $\begin{array}{l}\text { DPPC } \\
\text { DPPG }\end{array}$ & LPS & $\begin{array}{l}\text { Dehydration- } \\
\text { rehydration method }\end{array}$ \\
\hline Trifluralin & $\begin{array}{l}\text { Carvalheiro } \\
\text { et al. (2009) }\end{array}$ & $192 \pm 7$ and $187 \pm 17$ & - & $40 \pm 5$ and $38 \pm 4$ & $80 \pm 6$ and $81 \pm 12$ & $\begin{array}{l}\text { DOPC } \\
\text { DOPG }\end{array}$ & LPS & $\begin{array}{l}\text { lipid film hydration } \\
\text { with some } \\
\text { modifications }\end{array}$ \\
\hline $\begin{array}{l}\text { Trifluralin } \\
\text { analogues }\end{array}$ & $\begin{array}{l}\text { Carvalheiro } \\
\text { et al. (2015) }\end{array}$ & $170-200$ & $<0.2$ & $-(30$ a 47$)$ & 45 a 91 & $\begin{array}{l}\text { DMPC } \\
\text { DMPG }\end{array}$ & LPS & $\begin{array}{l}\text { lipid film-hydration } \\
\text { method followed by } \\
\text { extrusion }\end{array}$ \\
\hline Chalcone & $\begin{array}{l}\text { Koester et al. } \\
\text { (2015) }\end{array}$ & $171.9 \pm 18.7$ & $0.14 \pm 0.01$ & $-39.43 \pm 3.56$ & - & $\begin{array}{l}\text { Soybean } \\
\text { Lecithin }\end{array}$ & $\mathrm{NE}$ & $\begin{array}{l}\text { spontaneous } \\
\text { emulsification }\end{array}$ \\
\hline Amphotericin B & $\begin{array}{l}\text { Jung et al. } \\
\text { (2009) }\end{array}$ & $84.4 \pm 6.0$ & - & $-50.4 \pm 5.0$ & $76.5 \pm 5$ & $\begin{array}{l}\text { DPPC } \\
\text { CHOL } \\
\text { DSPE } \\
\text { DPPA }\end{array}$ & SLN & SESE method \\
\hline Oryzalin & $\begin{array}{l}\text { Lopes et al. } \\
\text { (2012) }\end{array}$ & $<140$ & $<0.2$ & -35 & $>75$ & Tripalmitin & SLN & $\begin{array}{l}\text { emulsification- } \\
\text { solvent }\end{array}$ \\
\hline $\begin{array}{l}\text { Amphotericin B } \\
\text { and } \\
\text { Miltefosine }\end{array}$ & $\begin{array}{l}\text { Pham et al. } \\
\text { (2014) }\end{array}$ & $250 \pm 2$ & $<0.1$ & $-2.3 \pm 0.6$ & $\begin{array}{l}54 \text { AMB } \\
59 \text { MILT }\end{array}$ & $\begin{array}{l}\text { CHOL } \\
\text { DOPS }\end{array}$ & SLN & hydrogel method \\
\hline Paromomycin & $\begin{array}{l}\text { Heidari- } \\
\text { Kharaji et al. } \\
(2016)\end{array}$ & 120 & $0.67 \pm 0.05$ & $532.43 \pm 164.40$ & $42-46$ & CHOL & SLN & $\begin{array}{l}\text { modified HSH } \\
\text { microemulsion } \\
\text { technique }\end{array}$ \\
\hline Buparvaquone & $\begin{array}{l}\text { Monteiro et al. } \\
\text { (2017a) }\end{array}$ & $<350$ & $<0.3$ & $<-21.0$ & 100 & $\begin{array}{l}\text { Miglyol } 182 \\
\text { Softisan } 154 \\
\text { WitepsolE85 }\end{array}$ & NLC & $\begin{array}{l}\text { high-pressure } \\
\text { homogenizer } \\
\text { method }\end{array}$ \\
\hline
\end{tabular}

Ref.: references; DPPG: dipalmitoyl phosphatidylglycerol, DPPC: dipalmitoyl phosphatidylcholine, DMPC: dimyristoylphosphatidylcholine, DMPG: dimyristoylphosphatidylglycerol, DOPC: dioleoylphosphatidylcholine, DOPG: dioleoylphosphatidylglycerol, DPPC: 1,2-dipalmitoyl-sn-glycero-3-phosphocholine, CHOL: cholesterol, DPPA: 1,2-dipalmitoyl-sn-glycero-3-phosphate (monoso- dium salt), DOPS: dioleoylphosphatidylserine, DSPE: 1,2-distearoyl-sn-glycero-3-phosphoethanolamine-N-[methoxy(polyethylene glycol)-2000] (ammonium salt), Chalcone: (E)-3-(3-nitrophenyl)-1-(3,4,5-trimethoxyphenyl) prop-2-en-1-one, LPS: liposome, NLC: nanostructured lipid carriers, SLN: solid lipid nanoparticles, NE: nanoemulsions, SESE: spontaneous emulsification and solvent evaporation, HSH: high shear homogenization, EE\%: encapsulation efficiency and PDI: polydispersity index.

2015).

Monteiro and coworkers (2017b) prepared hydroxymethylnitrofurazone (NFOH), a drug candidate, PBCA nanoparticle presenting encapsulation efficiency of $64.47 \pm 0.43 \%$. Where PBCANFOH-NPs demonstrated $\mathrm{IC}_{50}$ values of $0.33 \mu \mathrm{M}$ and $4.90 \mu \mathrm{M}$ for amastigotes and promastigotes of $L$. amazonensis, respectively. The selectivity index was 370.6 for PBCA-NFOH-NPs, which was a 49 -fold increase than free NFOH. The activity of PBCA-NFOH-NPs presented great efficacy for delivery aimed at macrophages (Monteiro et al., 2017b). The authors have filed a patent application for this invention (BR 102014 007923-8).

In a similar way, Britti et al. (2015) claimed ownership of intellectual property WO 2015177820 where polymer nanoparticles are employed as an effective vehicle for compounds based on antimony and antimonials, such as Glucantime ${ }^{\circledast}$. The system was prepared from an aqueous nucleus in which the active ingredient is entrapped, surrounded by a polymeric biocompatible and biodegradable shell based on PLA. This invention claims that the system allows reduction of cellular toxicity in treating this disease since the active ingredient is carried and concentrated only within the macrophages, avoiding systemic effects related to the therapy with antimonial medications (Britti et al.,2015).

Table 3 presents the properties of polymer nanoparticles for treating leishmaniasis. As can be observed, there are few studies proposing these nanoparticles possibly because of their limitations. In all procedures, the use of organic solvents was necessary with the exception of the method described by Monteiro and coworkers (2017b).

\subsection{Nanocrystal, an encapsulating-carrier free nanoparticle}

Nanocrystals are drug particles with crystalline or amorphous character in the submicron or nanometric range, generally between 100 and $500 \mathrm{~nm}$. The nanocrystals are solids formed by a network of atoms, ions or molecules, usually obtained by direct crystallization (bottom-up approach) or grinding (fragmentation) of the material (top-down approach) (Müller et al., 2011; Shegokar and Müller, 2010), composed exclusively of the drug (Möschwitzer, 2013; Müller et al., 2011) prepared in dispersion media using stabilizers (surfactants and/or polymers), resulting in a colloidal system. Thus, in the liquid medium, this system is called a nanosuspension (Müller et al., 2011; Rabinow, 2004).

Poor water-soluble drug substances represent $40 \%$ of the top 200 oral medicines marketed in the US, 33\% of drug substances listed in the US Pharmacopeia, $75 \%$ of drug candidates under development and $90 \%$ of molecules in the discovery pipeline (Rodriguez-Aller et al., 2015). Nanocrystals can improve the dissolution velocity and the saturation solubility of these drugs. The essence of the nanonization of poor watersoluble drug substances rests mainly on Noyes-Whitney equations (Noyes and Whitney, 1897) and Prandtl (1904). These equations describe how a decrease in particle size facilitates increasing the surface area and reducing the thickness of the diffusion layer, and thus, provides an increase in dissolution rate.

An additional advantage of nanocrystals refers to their greater adhesiveness compared to particles in the micrometer range in the biological membrane and surface of the gastrointestinal tract. As a result, drug absorption can be increased independent of the fed or fasting state (Müller et al., 2011). However, it is important to ensure the physical chemical properties of the drug nanocrystal during the manufacturing process and in storage throughout its shelf life (Chen et al., 2017) since these characteristics are critical for drug dissolution velocity in the nanosuspension.

Kayser et al (2003) develop a nanosuspension of AMB by highpressure homogenization, using polysorbate 80 and poloxamer P188. This formulation showed to be more active than micronized AMB for visceral leishmania model, after oral administration in rats. The reduction of parasite in liver was $28.6 \%$. In our group, Marins et al, (2017) reported a successful formulation using NFOH and polysorbate 
Table 3

Polymeric nanoparticle delivery systems for treating leishmaniasis.

\begin{tabular}{|c|c|c|c|c|c|c|c|}
\hline $\begin{array}{l}\text { Drug/active } \\
\text { substance }\end{array}$ & Ref. & Size $(\mathrm{nm})$ & PDI & Zeta Potential (mV) & $\mathrm{EE} \%$ & Polymers & Method of preparation \\
\hline AMB & $\begin{array}{l}\text { De Carvalho et al. } \\
\text { (2013) }\end{array}$ & $456.60 \pm 133.60$ & $0.431 \pm 0.001$ & $-32.60 \pm 4.64$ & - & $\begin{array}{l}\text { PLGA } \\
\text { DMSA }\end{array}$ & $\begin{array}{l}\text { method described by Amaral et al., with slight } \\
\text { modification }\end{array}$ \\
\hline AMB-MG & & $675.20 \pm 40.28$ & $0.584 \pm 0.001$ & $-28.00 \pm 4.86$ & & & $\begin{array}{l}\text { prepared by chemical condensation reaction of } \\
\text { aqueous ions in alkaline medium }\end{array}$ \\
\hline RIF & $\begin{array}{l}\text { Chaubey and } \\
\text { Mishra (2014) }\end{array}$ & $215.2 \pm 2.4$ & $0.109 \pm 0.18$ & $26.2 \pm 1.7$ & $39.1 \pm 6.3$ & $\begin{array}{l}\text { Chitosan } \\
\text { Mannose }\end{array}$ & $\begin{array}{l}\text { inducing the gelation method with suitable } \\
\text { modifications }\end{array}$ \\
\hline AMB & Kumar et al. (2015) & $30-35$ & - & - & - & PLGA & precipitation method \\
\hline $\mathrm{NFOH}$ & $\begin{array}{l}\text { Monteiro et al. } \\
\text { (2017b) }\end{array}$ & $151.50 \pm 61.97$ & $0.104 \pm 0.01$ & $-10.10 \pm 6.47$ & $64.47 \pm 0.43$ & PBCA & anionic emulsion polymerization method \\
\hline
\end{tabular}

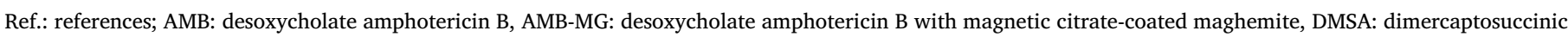

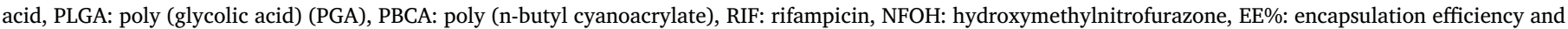
PDI: polydispersity index.

80. NFOH, a nitrofurazone reciprocal prodrug, is a promising drug candidate, which presented potential use in treating Chagas disease and leishmaniasis (Chung et al., 2003).

\section{Final considerations and future trends}

Considering the advantages and limitations, it is possible to identify a tendency in research into NanoDDS for treating leishmaniasis. Different nanosystems have been proposed in the last decade such as metallic, polymeric and lipid nanoparticles, liposomes and nanocrystals. Metallic nanoparticles have potential application as diagnostic and chemotherapeutic agents, although their toxicity has aroused concern. The synthetic polymers can be a challenge to regulatory agencies due to their diversity and consequent impact in safety and efficacy. Besides, natural polymers and their derivatives can present a high degree of variability due to it being obtained from an animal source.

A feasible industrial-scale manufacturing process allows an economically viable NanoDDS, which can be successfully introduced to the clinic and market. For this reason, the lipid nanoparticles obtained by high-pressure homogenization have been considered a promising delivery system. This well-established reliable and scale-up technology has the potential to improve the availability of affordable medicines. Besides this, for preparation the use of organic solvent is not necessary. However, this technology is not recommended for thermolabile and volatile drugs. Drug nanocrystal, an encapsulating-carrier free nanoparticle, can also be produced using this technology.

Nanosystems have the potential to play a key role in a major shift in treating leishmaniasis through macrophage-targeted delivery. It can reduce the duration of the treatment and frequency of administration by improving the adherence of patients to the therapy. A considerable number of studies demonstrate the in vivo efficacy of these therapies; however only liposomes $\left(\right.$ AmBisome ${ }^{\circledast}$ ) have reached the market. Unfortunately, this product is not affordable, preventing long-term availability of treatment and currently only benefiting a small proportion of patients worldwide. The present study revealed diverse innovative nanotherapies that are potentially safe and effective, which can provide an alternative for necessary competition to reduce the price of leishmaniasis treatment using state-of-art technology.

\section{Acknowledgments}

The authors thank Jim Hesson (James Joseph Hesson) of Academic English Solutions for the English language editing services of this manuscript http://www.AcademicEnglishSolutions.com), João Zamboni Pimont França for their contribution to the information related to the patent in this manuscript, CAPES (Coordenação de Aperfeiçoamento de Pessoal de Nível Superior) and CNPq (Conselho Nacional de Desenvolvimento Científico e Tecnológico).

\section{Funding sources}

This work was supported by "Fundaçao de Amparo a Pesquisa do Estado de Sao Paulo (FAPESP)" [grant number 2017/08332-3]

\section{References}

Abamor, E.S., Allahverdiyev, A.M., 2016. A nanotechnology based new approach for chemotherapy of Cutaneous Leishmaniasis: TIO2@AG nanoparticles - Nigella sativa oil combinations. Exp. Parasitol. 166, 150-163. http://dx.doi.org/10.1016/j. exppara.2016.04.008.

Ahlin Grabnar, P., Kristl, J., 2011. The manufacturing techniques of drug-loaded polymeric nanoparticles from preformed polymers. J. Microencapsul. 28, 323-335. http://dx.doi.org/10.3109/02652048.2011.569763.

Akhoundi, M., Kuhls, K., Cannet, A., Votýpka, J., Marty, P., Delaunay, P., Sereno, D., 2016. A historical overview of the classification, evolution, and dispersion of leishmania parasites and sandflies. PLoS Negl. Trop. Dis. 10, 1-40. http://dx.doi.org/10. 1371/journal.pntd.0004349.

Allahverdiyev, A., Abamor, E.S., Bagirova, M., Ustundag, C.B., Kaya, C., Kaya, F., Rafailovich, M., 2011. Antileishmanial effect of silver nanoparticles and their enhanced antiparasitic activity under ultraviolet light. Int. J. Nanomed. 6, 2705-2714. http://dx.doi.org/10.2147/IJN.S23883.

Allahverdiyev, A.M., Abamor, E.S., Bagirova, M., Baydar, S.Y., Ates, S.C., Kaya, F., Kaya, C., Rafailovich, M., 2013. Investigation of antileishmanial activities of TiO2@Ag nanoparticles on biological properties of L. tropica and L. infantum parasites, in vitro. Exp. Parasitol. 135, 55-63. http://dx.doi.org/10.1016/j.exppara.2013.06.001.

Anton, N., Benoit, J.-P., Saulnier, P., 2008. Design and production of nanoparticles formulated from nano-emulsion templates-a review. J. Control. Release 128, 185-199. http://dx.doi.org/10.1016/j.jconrel.2008.02.007.

Arokiyaraj, S., Saravanan, M., Bharanidharan, R., Islam, V.I.H., Bououdina, M., Vincent, S., 2016. Green Synthesis of Metallic Nanoparticles Using Plant Compounds and Their Applications, Emerging Research on Bioinspired Materials Engineering. IGI Global 10.4018/978-1-4666-9811-6.ch001.

Attama, A.A., Momoh, M.A., Builders, P.F., 2012. Lipid Nanoparticulate Drug Delivery Systems: A Revolution in Dosage Form Design and Development, Recent Advances in Novel Drug Carrier Systems. InTech 10.5772/50486.

Baek, J.S., Cho, C.W., 2017. Surface modification of solid lipid nanoparticles for oral delivery of curcumin: Improvement of bioavailability through enhanced cellular uptake, and lymphatic uptake. Eur. J. Pharm. Biopharm. 117, 132-140. http://dx. doi.org/10.1016/j.ejpb.2017.04.013.

Bafghi, A.F., Daghighi, M., Daliri, K., Jebali, A., 2015. Magnesium oxide nanoparticles coated with glucose can silence important genes of Leishmania major at sub-toxic concentrations. Colloids Surf., B 136, 300-304. http://dx.doi.org/10.1016/j.colsurfb. 2015.09 .029$.

Baiocco, P., Ilari, A., Ceci, P., Orsini, S., Gramiccia, M., Di Muccio, T., Colotti, G., 2011 Inhibitory effect of silver nanoparticles on trypanothione reductase activity and Leishmania infantum proliferation. ACS Med. Chem. Lett. 2, 230-233. http://dx.doi. org $/ 10.1021 / \mathrm{ml} 1002629$.

Bangham, A.D., Standish, M.M., Watkins, J.C., 1965. Diffusion of univalent ions across the lamellae of swollen phospholipids. J. Mol. Biol. 13, 238-252. http://dx.doi.org/ 10.1016/S0022-2836(65)80093-6.

Banik, B.L., Fattahi, P., Brown, J.L., 2016. Polymeric nanoparticles: the future of nanomedicine. Wiley Interdiscip. Rev. Nanomed. Nanobiotechnol. 8, 271-299. http://dx. doi.org/10.1002/wnan.1364.

Beg, S., Saini, S., Imam, S., Rahman, M., Swain, S., Hasnain, M.S., 2017. Nanoemulsion for the effective treatment and management of anti-tubercular drug therapy. Recent Pat. Antiinfect. Drug Discov. 12, 1-10. http://dx.doi.org/10.2174/ $1574891 X 12666170504094330$.

Beheshti, N., Soflaei, S., Shakibaie, M., Yazdi, M.H., Ghaffarifar, F., Dalimi, A., Shahverdi, A.R., 2013. Efficacy of biogenic selenium nanoparticles against Leishmania major: In vitro and in vivo studies. J. Trace Elem. Med. Biol. 27, 203-207. http://dx.doi.org/ 10.1016/j.jtemb.2012.11.002. 
Bekersky, I., Fielding, R.M., Dressler, D.E., Lee, J.W., Buell, D.N., Walsh, T.J., 2002. Plasma protein binding of amphotericin $\mathrm{B}$ and pharmacokinetics of bound versus unbound amphotericin B after administration of intravenous liposomal amphotericin B (AmBisome) and amphotericin B deoxycholate. Antimicrob. Agents Chemother. 46, 834-840. http://dx.doi.org/10.1128/AAC.46.3.834-840.2002.

Borghi, S.M., Fattori, V., Conchon-Costa, I., Pinge-Filho, P., Pavanelli, W.R., Verri, W.A., 2017. Leishmania infection: painful or painless? Parasitol. Res. 116, 465-475. http:// dx.doi.org/10.1007/s00436-016-5340-7.

Britti, D., Cosco, D., Fresta, M., Paolino, D., Trapasso, E., 2015. (WO/2015/177820) Nanoparticulate systems for vehiculating drugs for the treatment of leishmania infection-related pathologies. PCT/IT2015/000134.

Bulbake, U., Doppalapudi, S., Kommineni, N., Khan, W., 2017. Liposomal formulations in clinical use: an updated review. Pharmaceutics 9, 12. http://dx.doi.org/10.3390/ pharmaceutics9020012.

Caliph, S.M., Charman, W.N., Porter, C.J.H., 2000. Effect of short-, medium-, and long chain fatty acid-based vehicles on the absolute oral bioavailability and intestinal lymphatic transport of halofantrine and assessment of mass balance in lymph-cannulated and non-cannulated rats. J. Pharm. Sci. 89, 1073-1084. http://dx.doi.org/ 10.1002/1520-6017(200008)89:8 < 1073::AID-JPS12>3.0.CO;2-V.

Carvalheiro, M., Esteves, M.A., Santos-Mateus, D., Lopes, R.M., Rodrigues, M.A. Eleutério, C.V., Scoulica, E., Santos-Gomes, G., Cruz, M.E.M., 2015. Hemisynthetic trifluralin analogues incorporated in liposomes for the treatment of leishmanial in fections. Eur. J. Pharm. Biopharm. 93, 346-352. http://dx.doi.org/10.1016/j.ejpb. 2015.04.018.

Carvalheiro, M., Jorge, J., Eleutério, C., Pinhal, A.F., Sousa, A.C., Morais, J.G., Cruz, M.E.M., 2009. Trifluralin liposomal formulations active against Leishmania donovani infections. Eur. J. Pharm. Biopharm. 71, 292-296. http://dx.doi.org/10.1016/j.ejpb. 2008.08.001.

Chaloupka, K., Malam, Y., Seifalian, A.M., 2010. Nanosilver as a new generation of nanoproduct in biomedical applications. Trends Biotechnol. 28, 580-588. http://dx.doi. org/10.1016/j.tibtech.2010.07.006

Charman, W.N.A., Stella, V.J., 1986. Estimating the maximal potential for intestinal lymphatic transport of lipophilic drug molecules. Int. J. Pharm. 34, 175-178. http:// dx.doi.org/10.1016/0378-5173(86)90027-X.

Chattopadhyay, A., Jafurulla, M., 2011. A novel mechanism for an old drug: Amphotericin B in the treatment of visceral leishmaniasis. Biochem. Biophys. Res. Commun. 416, 7-12. http://dx.doi.org/10.1016/j.bbrc.2011.11.023.

Chaubey, P., Mishra, B., 2014. Mannose-conjugated chitosan nanoparticles loaded with rifampicin for the treatment of visceral leishmaniasis. Carbohydr. Polym. 101, 1101-1108. http://dx.doi.org/10.1016/j.carbpol.2013.10.044.

Chen, M.-L., John, M., Lee, S.L., Tyner, K.M., 2017. Development considerations for nanocrystal drug products. AAPS J. 19, 642-651. http://dx.doi.org/10.1208/s12248017-0064-X.

Chung, M.-C., Güido, R.V.C., Martinelli, T.F., Gonçalves, M.F., Polli, M.C., Botelho, K.C.A., Varanda, E.A., Colli, W., Miranda, M.T.M., Ferreira, E.I., 2003. Synthesis and in vitro evaluation of potential antichagasic hydroxymethylnitrofurazone (NFOH121): a new nitrofurazone prodrug. Bioorg. Med. Chem. 11, 4779-4783. http://dx. doi.org/10.1016/j.bmc.2003.07.004.

Coelho, E., Ribeiro, T., Fuscaldi, L., Santos, M., Duarte, M., Lage, P., Martins, V., Costa, L., Diniz, S., Cardoso, V., Castilho, R., Soto, M., Tavares, C.A., Fumagalli, M., Ribeiro, J., Faraco, A., 2014. An optimized nanoparticle delivery system based on chitosan and chondroitin sulfate molecules reduces the toxicity of amphotericin B and is effective in treating tegumentary leishmaniasis. Int. J. Nanomed. 19, 5341-5353. http://dx. doi.org/10.2147/IJN.S68966.

Costa Lima, S.A., Silvestre, R., Barros, D., Cunha, J., Baltazar, M.T., Dinis-Oliveira, R.J., Cordeiro-da-Silva, A., 2014. Crucial CD8 + T-lymphocyte cytotoxic role in amphotericin B nanospheres efficacy against experimental visceral leishmaniasis. Nanomed. Nanotechnol. Biol. Med. 10, 1021-1030. http://dx.doi.org/10.1016/j.nano.2013.12. 013.

Crovetto-Martínez, R., Aguirre-Urizar, J.M., Orte-Aldea, C., Araluce-Iturbe, I., WhyteOrozco, J., Crovetto-De La Torre, M.A., 2015. Mucocutaneous leishmaniasis must be included in the differential diagnosis of midline destructive disease: two case reports. Oral Surg. Oral Med. Oral Pathol. Oral Radiol. 119, 20-26. http://dx.doi.org/10. 1016/j.0ooo.2014.09.008

Cui, H., Zhao, C., Lin, L., 2015. The specific antibacterial activity of liposome-encapsulated Clove oil and its application in tofu. Food Control 56, 128-134. http://dx. doi.org/10.1016/j.foodcont.2015.03.026.

Das, S., Roy, P., Mondal, S., Bera, T., Mukherjee, A., 2013. One pot synthesis of gold nanoparticles and application in chemotherapy of wild and resistant type visceral leishmaniasis. Colloids Surf., B 107, 27-34. http://dx.doi.org/10.1016/j.colsurfb. 2013.01.061.

Date, A.A., Joshi, M.D., Patravale, V.B., 2007. Parasitic diseases: liposomes and polymeric nanoparticles versus lipid nanoparticles. Adv. Drug Deliv. Rev. 59, 505-521. http:// dx.doi.org/10.1016/j.addr.2007.04.009.

De Carvalho, R.F., Ribeiro, I.F., Miranda-Vilela, A.L., de Souza Filho, J., Martins, O.P., de Oliveira Cintra e Silva, D., Tedesco, A.C., Lacava, Z.G.M., Báo, S.N., Sampaio, R.N.R., 2013. Leishmanicidal activity of amphotericin B encapsulated in PLGA-DMSA nanoparticles to treat cutaneous leishmaniasis in C57BL/6 mice. Exp. Parasitol. 135, 217-222. http://dx.doi.org/10.1016/j.exppara.2013.07.008.

Delavari, M., Dalimi, A., Ghaffarifar, F., Sadraei, J., 2014. In vitro study on cytotoxic effects of $\mathrm{ZnO}$ nanoparticles on promastigote and amastigote forms of Leishmania major (MRHO/IR/75/ER). Iran. J. Parasitol. 9, 6-13.

Dimer, F.A., Friedrich, R.B., Beck, R.C.R., Guterres, S.S., Pohlmann, A.R., 2013. Impactos da nanotecnologia na saúde: produção de medicamentos. Quim. Nova 36, 1520-1526. http://dx.doi.org/10.1590/S0100-40422013001000007.

Djurišić, A.B., Leung, Y.H., Ng, A.M.C., Xu, X.Y., Lee, P.K.H., Degger, N., Wu, R.S.S., 2015.
Toxicity of metal oxide nanoparticles: mechanisms, characterization, and avoiding experimental artefacts. Small 11, 26-44. http://dx.doi.org/10.1002/smll. 201303947.

Duncan, R., 2011. Polymer therapeutics as nanomedicines: new perspectives. Curr. Opin. Biotechnol. 22, 492-501. http://dx.doi.org/10.1016/j.copbio.2011.05.507.

Eifler, A.C., Thaxton, C.S., 2011. Nanoparticle therapeutics: FDA approval, clinical trials, regulatory pathways, and case study. Methods Mol. Biol. (Clifton, N.J.) 325-338. http://dx.doi.org/10.1007/978-1-61779-052-2_21.

Ekiz, O., Kahraman, S., Sen, B., Serarslan, G., Rifaioğlu, E., Culha, G., Özgür, T., 2017. Mucocutaneous leishmaniasis with marked facial disfigurement. Indian J. Dermatology. Venereol. Leprol. 83, 91-93. http://dx.doi.org/10.4103/0378-6323. 190848.

Fryd, M.M., Mason, T.G., 2012. Advanced Nanoemulsions. Annu. Rev. Phys. Chem. 63, 493-518. http://dx.doi.org/10.1146/annurev-physchem-032210-103436.

Gasco, M.R., Gallarate, M., Pattarino, F., 1991. In vitro permeation of azelaic acid from viscosized microemulsions. Int. J. Pharm. 69, 193-196. http://dx.doi.org/10.1016/ 0378-5173(91)90361-Q.

Gaspar, M., Cruz, A., Fraga, A., Castro, A., Cruz, M., Pedrosa, J., 2008a. Developments on drug delivery systems for the treatment of mycobacterial infections. Curr. Top. Med. Chem. 8, 579-591. http://dx.doi.org/10.2174/156802608783955629.

Gaspar, M.M., Calado, S., Pereira, J., Ferronha, H., Correia, I., Castro, H., Tomás, A.M., Cruz, M.E.M., 2015. Targeted delivery of paromomycin in murine infectious disease through association to nano lipid systems. Nanomed. Nanotechnol. Biol. Med. 11, 1851-1860. http://dx.doi.org/10.1016/j.nano.2015.06.008.

Gaspar, M.M., Cruz, A., Penha, A.F., Reymão, J., Sousa, A.C., Eleutério, C.V., Domingues, S.A., Fraga, A.G., Filho, A.L., Cruz, M.E.M., Pedrosa, J., 2008b. Rifabutin encapsulated in liposomes exhibits increased therapeutic activity in a model of disseminated tuberculosis. Int. J. Antimicrob. Agents 31, 37-45. http://dx.doi.org/10. 1016/j.ijantimicag.2007.08.008.

Gaspar, R., Duncan, R., 2009. Polymeric carriers: preclinical safety and the regulatory implications for design and development of polymer therapeutics. Adv. Drug Deliv. Rev. 61, 1220-1231. http://dx.doi.org/10.1016/j.addr.2009.06.003.

Gupta, S., Pal, A., Vyas, S.P., 2010. Drug delivery strategies for therapy of viscera leishmaniasis. Expert Opin. Drug Deliv. 7, 371-402. http://dx.doi.org/10.1517/ 17425240903548232

Heidari-Kharaji, M., Taheri, T., Doroud, D., Habibzadeh, S., Badirzadeh, A., Rafati, S. 2016. Enhanced paromomycin efficacy by solid lipid nanoparticle formulation against Leishmania in mice model. Parasite Immunol. 38, 599-608. http://dx.doi. org/10.1111/pim.12340.

Herwaldt, B.L., 1999. Leishmaniasis. Lancet 354, 1191-1199. http://dx.doi.org/10.1016/ S0140-6736(98)10178-2.

Ibrahim, F., Gershkovich, P., Sivak, O., Wasan, E.K., Wasan, K.M., 2013 Pharmacokinetics and tissue distribution of amphotericin B following oral administration of three lipid-based formulations to rats. Drug Dev. Ind. Pharm. 39, 1277-1283. http://dx.doi.org/10.3109/03639045.2012.719908.

Iravani, S., 2011. Green synthesis of metal nanoparticles using plants. Green Chem. 13, 2638-2650. http://dx.doi.org/10.1039/c1gc15386b.

Jaiswal, M., Dudhe, R., Sharma, P.K., 2015. Nanoemulsion: an advanced mode of drug delivery system. 3 Biotech 5, 123-127. http://dx.doi.org/10.1007/s13205-0140214-0.

Jebali, A., Kazemi, B., 2013. Nano-based antileishmanial agents: a toxicological study on nanoparticles for future treatment of cutaneous leishmaniasis. Toxicol. Vitr. 27, 1896-1904. http://dx.doi.org/10.1016/j.tiv.2013.06.002.

Jung, S.H., Lim, D.H., Jung, S.H., Lee, J.E., Jeong, K.-S., Seong, H., Shin, B.C., 2009. Amphotericin B-entrapping lipid nanoparticles and their in vitro and in vivo characteristics. Eur. J. Pharm. Sci. 37, 313-320. http://dx.doi.org/10.1016/j.ejps.2009. 02.021.

Kalangi, S.K., Dayakar, A., Gangappa, D., Sathyavathi, R., Maurya, R.S., Narayana Rao, D., 2016. Biocompatible silver nanoparticles reduced from Anethum graveolens leaf extract augments the antileishmanial efficacy of miltefosine. Exp. Parasitol. 170 184-192. http://dx.doi.org/10.1016/j.exppara.2016.09.002.

Kalepu, S., Nekkanti, V., 2015. Insoluble drug delivery strategies: review of recent advances and business prospects. Acta Pharm. Sin. B 5, 442-453. http://dx.doi.org/10. 1016/j.apsb.2015.07.003.

Kayser, O., Olbrich, C., Yardley, V., Kiderlen, A.F., Croft, S.L., 2003. Formulation of amphotericin B as nanosuspension for oral administration. Int. J. Pharm. 254, 73-75. http://dx.doi.org/10.1016/S0378-5173(02)00686-5.

Kelly, C., Jefferies, C., Cryan, S.-A., 2011. Targeted liposomal drug delivery to monocytes and macrophages. J. Drug Deliv. 2011, 1-11. http://dx.doi.org/10.1155/2011 727241.

Kevric, I., Cappel, M.A., Keeling, J.H., 2015. New world and old world leishmania infections: a practical review. Dermatol. Clin. 33, 579-593. http://dx.doi.org/10.1016/ j.det.2015.03.018.

Kharaji, M.H., Doroud, D., Taheri, T., Rafati, S., 2015. Drug targeting to macrophages with solid lipid nanoparticles harboring paromomycin: an in vitro evaluation against L. major and L. tropica. AAPS PharmSciTech 17, 13-15. http://dx.doi.org/10.1208/ s12249-015-0439-1.

Kip, A.E., Schellens, J.H.M., Beijnen, J.H., Dorlo, T.P.C., 2018. Clinical pharmacokinetics of systemically administered antileishmanial drugs. Clin. Pharmacokinet. 57, 151-176. http://dx.doi.org/10.1007/s40262-017-0570-0.

Kobets, T., Grekov, I., Lipoldova, M., 2012. Leishmaniasis: prevention, parasite detection and treatment. Curr. Med. Chem. 19, 1443-1474. http://dx.doi.org/10.2174/ 092986712799828300

Koester, L., Mattos, C., Argenta, D., Melchiades, G., Cordeiro, M., Tonini, M., Moraes, M., Weber, T., Roman, S., Nunes, R., Teixeira, H., Steindel, M., 2015. Nanoemulsions containing a synthetic chalcone as an alternative for treating cutaneous leshmaniasis: 
optimization using a full factorial design. Int. J. Nanomed. 10, 5529-5542. http://dx. doi.org/10.2147/IJN.S83929.

Kolenyak-Santos, F., Garnero, C., De Oliveira, R.N., de Souza, A.L.R., Chorilli, M., Allegretti, S.M., Longhi, M.R., Chaud, M.V., Gremião, M.P.D., 2015. Nanostructured lipid carriers as a strategy to improve the in vitro schistosomiasis activity of praziquantel. J. Nanosci. Nanotechnol. 15, 761-772. http://dx.doi.org/10.1166/jnn.2015 9186.

Koroleva, M.Y., Yurtov, E.V., 2012. Nanoemulsions: the properties, methods of preparation and promising applications. Russ. Chem. Rev. 81, 21-43. http://dx.doi.org/10 1070/RC2012v081n01ABEH004219.

Kumar, C.S.S.R., Mohammad, F., 2011. Magnetic nanomaterials for hyperthermia-based therapy and controlled drug delivery. Adv. Drug Deliv. Rev. 63, 789-808. http://dx. doi.org/10.1016/j.addr.2011.03.008.

Kumar, R., Sahoo, G.C., Pandey, K., Das, V., Das, P., 2015. Study the effects of PLGA-PEG encapsulated Amphotericin B nanoparticle drug delivery system against Leishmania donovani. Drug Deliv. 22, 383-388. http://dx.doi.org/10.3109/10717544.2014. 891271.

Lestner, J.M., Groll, A.H., Aljayyoussi, G., Seibel, N.L., Shad, A., Gonzalez, C., Wood, L.V., Jarosinski, P.F., Walsh, T.J., Hope, W.W., 2016. Population pharmacokinetics of liposomal amphotericin B in immunocompromised children. Antimicrob. Agents Chemother. 60, 7340-7346. http://dx.doi.org/10.1128/AAC.01427-16.

Lopes, R., Eleutério, C.V., Gonçalves, L.M.D., Cruz, M.E.M., Almeida, A.J., 2012. Lipid nanoparticles containing oryzalin for the treatment of leishmaniasis. Eur. J. Pharm. Sci. 45, 442-450. http://dx.doi.org/10.1016/j.ejps.2011.09.017.

Marins, D., Araújo, G., Löbenberg, R., Bou-Chacra, N.A., 2017. Hydroxymethylnitrofurazone nanocrystals (NFOH): a promising therapeutic approach in the treatment of leishmaniasis, in: AAPS Annual Meeting and Exposition. San Diego.

Mayelifar, K., Taheri, A.R., Rajabi, O., Sazgarnia, A., 2015. Ultraviolet B efficacy in improving antileishmanial effects of silver nanoparticles. Iran. J. Basic Med. Sci. 18, 677-683.

Mcgwire, B.S., Satoskar, A.R., 2014. Leishmaniasis: clinical syndromes and treatment. QJM 107, 7-14. http://dx.doi.org/10.1093/qjmed/hct116.

Ministério da Saúde, 2017a. Casos confirmados de Leishmaniose Visceral, Brasil, Grandes Regiões e Unidades Federadas. 1990 a 2016.

Ministério da Saúde, 2017b. Casos de leishmaniose visceral no Brasil, 1980 a 2015.

Ministério da Saúde, 2017c. Letalidade de Leishmaniose Visceral. Brasil, Grandes Regiões e Unidades Federadas. 2000 a 2016.

Ministério da Saúde, 2017d. Casos de Leishmaniose Tegumentar. Brasil, Grandes Regiões e Unidades Federadas. 1990 a 2016.

Minodier, P., Parola, P., 2007. Cutaneous leishmaniasis treatment. Travel Med. Infect. Dis. 5, 150-158. http://dx.doi.org/10.1016/j.tmaid.2006.09.004.

Mody, V.V., Siwale, R., Singh, A., Mody, H.R., 2010. Introduction to metallic nanoparticles. J. Pharm. bioallied Sci. 2, 282-289. http://dx.doi.org/10.4103/0975-7406. 72127.

Mohebali, M., Rezayat, M.M., Gilani, K., Sarkar, S., Akhoundi, B., Esmaeili, J., Satvat, T., Elikaee, S., Charehdar, S., Hooshyar, H., 2009. Nanosilver in the treatment of localized cutaneous leishmaniasis caused by Leishmania major (MRHO/IR/75/ER): an in vitro and in vivo study. DARU-J. Fac. Pharm. 17, 285-289.

Monteiro, L.M., Löbenberg, R., Cotrim, P.C., Barros de Araujo, G.L., Bou-Chacra, N., 2017a. Buparvaquone nanostructured lipid carrier: development of an affordable delivery system for the treatment of leishmaniases. Biomed. Res. Int. 2017, 1-11. http://dx.doi.org/10.1155/2017/9781603.

Monteiro, L.M., Löbenberg, R., Ferreira, E.I., Cotrim, P.C., Kanashiro, E., Rocha, M., Chung, M.C., Bou-Chacra, N., 2017b. Targeting Leishmania amazonensis amastigotes through macrophage internalisation of a hydroxymethylnitrofurazone nanostructured polymeric system. Int. J. Antimicrob. Agents 50, 88-92. http://dx.doi.org/ 10.1016/j.ijantimicag.2017.01.033.

Morilla, M.J., Romero, E.L., 2015. Nanomedicines against Chagas disease: an update on therapeutics, prophylaxis and diagnosis. Nanomedicine (Lond) 10, 465-481. http:// dx.doi.org/10.2217/nnm.14.185.

Möschwitzer, J.P., 2013. Drug nanocrystals in the commercial pharmaceutical development process. Int. J. Pharm. 453, 142-156. http://dx.doi.org/10.1016/j.ijpharm. 2012.09.034.

Mouri, R., Konoki, K., Matsumori, N., Oishi, T., Murata, M., 2008. Complex formation of amphotericin B in sterol-containing membranes as evidenced by surface plasmon resonance. Biochemistry 47, 7807-7815. http://dx.doi.org/10.1021/bi800334p.

Müller, R.H., Gohla, S., Keck, C.M., 2011. State of the art of nanocrystals - special features, production, nanotoxicology aspects and intracellular delivery. Eur. J. Pharm. Biopharm. 78, 1-9. http://dx.doi.org/10.1016/j.ejpb.2011.01.007.

Müller, R.H., Radtke, M., Wissing, S.A., 2002. Solid lipid nanoparticles (SLN) and nanostructured lipid carriers (NLC) in cosmetic and dermatological preparations. Adv. Drug Deliv. Rev. 54, S131-S155. http://dx.doi.org/10.1016/S0169-409X(02) 00118-7.

Nagarsekar, K., Ashtikar, M., Steiniger, F., Thamm, J., Schacher, F., Fahr, A., 2016. Understanding cochleate formation: insights into structural development. Soft Matter 12, 3797-3809. http://dx.doi.org/10.1039/C5SM01469G.

Naseri, N., Valizadeh, H., Zakeri-milani, P., 2015. Solid lipid nanoparticles and nanostructured lipid carriers : structure, preparation and application. Tabriz Univ. Med. Sci. 5, 305-313. http://dx.doi.org/10.15171/apb.2015.043.

Neuber, H., 2008. Leishmaniasis. J. der Dtsch. Dermatologischen Gesellschaft 6, 754-765. http://dx.doi.org/10.1111/j.1610-0387.2008.06809.x.

New, R.R.C., Chance, M.L., Heath, S., 1981. Antileishmanial activity of amphotericin and other antifungal agents entrapped in liposomes. J. Antimicrob. Chemother. 8, 371-381. http://dx.doi.org/10.1093/jac/8.5.371.

Niazi, J.H., Gu, M. B, 2009. Toxicity of metallic nanoparticles in microorganisms-a review. In: Atmospheric and Biological Environmental Monitoring. Springer Netherlands, Dordrecht, pp. 193-206. http://dx.doi.org/10.1007/978-1-4020-9674 712.

Noyes, A.A., Whitney, W.R., 1897. The rate of solution of solid substances in their own solutions. J. Am. Chem. Soc 19, 930-934.

Omwoyo, W.N., Melariri, P., Gathirwa, J.W., Oloo, F., Mahanga, G.M., Kalombo, L., Ogutu, B., Swai, H., 2016. Development, characterization and antimalarial efficacy of dihydroartemisinin loaded solid lipid nanoparticles. Nanomed. Nanotechnol.Biol. Med. 12, 801-809. http://dx.doi.org/10.1016/j.nano.2015.11.017.

Paila, Y.D., Saha, B., Chattopadhyay, A., 2010. Amphotericin B inhibits entry of Leishmania donovani into primary macrophages. Biochem. Biophys. Res. Commun. 399, 429-433. http://dx.doi.org/10.1016/j.bbrc.2010.07.099.

Paliwal, R., Rai, S., Vaidya, B., Khatri, K., Goyal, A.K., Mishra, N., Mehta, A., Vyas, S.P., 2009. Effect of lipid core material on characteristics of solid lipid nanoparticles designed for oral lymphatic delivery. Nanomed. Nanotechnol. Biol. Med. 5, 184-191. http://dx.doi.org/10.1016/j.nano.2008.08.003.

Palumbo, E., 2010. Treatment strategies for mucocutaneous leishmaniasis. J. Glob. Infect. Dis. 2, 147-150. http://dx.doi.org/10.4103/0974-777X.62879.

Pan American Health Organization, 2017. Leishmaniasis: Epidemiological Report in the Americas: Washington.

Panáček, A., Kvítek, L., Prucek, R., Kolář, M., Večeřová, R., Pizúrová, N., Sharma, V.K., Nevěčná, T., Zbořil, R., 2006. Silver colloid nanoparticles: synthesis, characterization, and their antibacterial activity. J. Phys. Chem. B 110, 16248-16253. http://dx.doi. org/10.1021/jp063826h.

Parashar, D., Aditya, N.P., Murthy, R.S.R., 2016. Development of artemether and lumefantrine co-loaded nanostructured lipid carriers: physicochemical characterization and in vivo antimalarial activity. Drug Deliv. 23, 123-129. http://dx.doi.org/10. 3109/10717544.2014.905883.

Pham, T.T.H., Gueutin, C., Cheron, M., Abreu, S., Chaminade, P., Loiseau, P.M., Barratt, G., 2014. Development of antileishmanial lipid nanocomplexes. Biochimie 107 143-153. http://dx.doi.org/10.1016/j.biochi.2014.06.007.

Pham, T.T.H., Loiseau, P.M., Barratt, G., 2013. Strategies for the design of orally bioavailable antileishmanial treatments. Int. J. Pharm. 454, 539-552. http://dx.doi.org/ 10.1016/j.ijpharm.2013.07.035

Poonia, N., Kharb, R., Lather, V., Pandita, D., 2016. Nanostructured lipid carriers: versatile oral delivery vehicle. Futur. Sci. OA 2, FSO135. http://dx.doi.org/10.4155/ fsoa-2016-0030.

Prandtl, L., 1904. Über Flussigkeitsbewegungen Bei Sehr Kleiner Reibung. Verhandlungen des dritten Int. Math. Kongresses Heidelberg, 484-491. https://doi.org/citeulikearticle-id:8770463.

Pucadyil, T.J., Tewary, P., Madhubala, R., Chattopadhyay, A., 2004. Cholesterol is required for Leishmania donovani infection: implications in leishmaniasis. Mol. Biochem. Parasitol. 133, 145-152. http://dx.doi.org/10.1016/j.molbiopara.2003.10. 002.

Rabinow, B.E., 2004. Nanosuspensions in drug delivery. Nat. Rev. Drug Discov. 3 , 785-796. http://dx.doi.org/10.1038/nrd1494.

Ramos, H., Valdivieso, E., Gamargo, M., Dagger, F., Cohen, B.E., 1996. Amphotericin B kills unicellular leishmanias by forming aqueous pores permeable to small cations and anions. J. Membr. Biol. 152, 65-75. http://dx.doi.org/10.1007/s002329900086.

Readio, J.D., Bittman, R., 1982. Equilibrium binding of amphotericin B and its methyl ester and borate complex to sterols. BBA - Biomembr. 685, 219-224. http://dx.doi. org/10.1016/0005-2736(82)90103-1.

Rodriguez-Aller, M., Guillarme, D., Veuthey, J.-L., Gurny, R., 2015. Strategies for formulating and delivering poorly water-soluble drugs. J. Drug Deliv. Sci. Technol. 30 342-351. http://dx.doi.org/10.1016/j.jddst.2015.05.009.

Saffie-Siebert, R., Ogden, J., Parry-Billings, M., 2005. Nanotechnology approaches to solving the problems of poorly water-soluble drugs. Drug Discov. World 6, 71-76.

Sagitani, H., Nabeta, K., Nagai, M., 1991. A new preparing method for fine O/W emulsions by D phase emulsification and their application to cosmetic industry. J. Japan Oil Chem. Soc. 40, 988-994. http://dx.doi.org/10.5650/jos1956.40.988.

Saha, A.K., Mukherjee, T., Bhaduri, A., 1986. Mechanism of action of amphotericin B on Leishmania donovani promastigotes. Mol. Biochem. Parasitol. 19, 195-200. http://dx. doi.org/10.1016/0166-6851(86)90001-0.

Salouti, M., Ahangari, A., 2014. Nanoparticle based drug delivery systems for treatmen of infectious diseases. In: Application of Nanotechnology in Drug Delivery. InTech. http://dx.doi.org/10.5772/58423.

Seibel, N.L., Shad, A.T., Bekersky, I., Groll, A.H., Gonzalez, C., Wood, L.V., Jarosinski, P., Buell, D., Hope, W.W., Walsh, T.J., 2017. Safety, tolerability, and pharmacokinetics of liposomal amphotericin b in immunocompromised pediatric patients. Antimicrob. Agents Chemother. 61. http://dx.doi.org/10.1128/AAC.01477-16.

Shakibaie, M., Khorramizadeh, M.R., Faramarzi, M.A., Sabzevari, O., Shahverdi, A.R., 2010. Biosynthesis and recovery of selenium nanoparticles and the effects on matrix metalloproteinase-2 expression. Biotechnol. Appl. Biochem. 56, 7-15. http://dx.doi. org/10.1042/BA20100042.

Sharma, A., Sharma, U., 1997. Liposomes in drug delivery: progress and limitations. Int J. Pharm. 154, 123-140. http://dx.doi.org/10.1016/S0378-5173(97)00135-X.

Sharma, M., Sharma, R., Jain, D.K., 2016. Nanotechnology based approaches for en hancing oral bioavailability of poorly water soluble antihypertensive drugs. Scientifica (Cairo) 2016, 1-11. http://dx doi org/10.1155/2016/8525679.

Shegokar, R., Müller, R.H., 2010. Nanocrystals: Industrially feasible multifunctional formulation technology for poorly soluble actives. Int. J. Pharm. 399, 129-139. http://dx.doi.org/10.1016/j.ijpharm.2010.07.044.

Siefert, A.L., Ehrlich, A., Corral, M.J., Goldsmith-Pestana, K., McMahon-Pratt, D., Fahmy, T.M., 2016. Immunomodulatory nanoparticles ameliorate disease in the Leishmania (Viannia) panamensis mouse model. Biomaterials 108, 168-176. http://dx.doi.org/ 10.1016/j.biomaterials.2016.09.004. 
Soares-bezerra, R.J., Leon, L., Genestra, M., 2004. Recentes avanços da quimioterapia das leishmanioses: moléculas intracelulares como alvo de fármacos. Rev. Bras. Ciências Farm. 40, 139-149. http://dx.doi.org/10.1590/S1516-93322004000200003.

Soema, P.C., Willems, G.-J., Jiskoot, W., Amorij, J.-P., Kersten, G.F., 2015. Predicting the influence of liposomal lipid composition on liposome size, zeta potential and liposome-induced dendritic cell maturation using a design of experiments approach. Eur. J. Pharm. Biopharm. 94, 427-435. http://dx.doi.org/10.1016/j.ejpb.2015.06.026.

Strazzulla, A., Cocuzza, S., Pinzone, M.R., Postorino, M.C., Cosentino, S., Serra, A., Cacopardo, B., Nunnari, G., 2013. Mucosal leishmaniasis: an underestimated presentation of a neglected disease. Biomed Res. Int. 2013, 1-7. http://dx.doi.org/10. 1155/2013/805108.

Sundar, S., Chakravarty, J., Agarwal, D., Rai, M., Murray, H.W., 2010. Single-dose liposomal amphotericin B for visceral leishmaniasis in India. N. Engl. J. Med. 362, 504-512. http://dx.doi.org/10.1056/NEJMoa0903627.

Tsai, M.J., Wu, P.C., Huang, Y. Bin, Chang, J.S., Lin, C.L., Tsai, Y.H., Fang, J.Y., 2012. Baicalein loaded in tocol nanostructured lipid carriers (tocol NLCs) for enhanced stability and brain targeting. Int. J. Pharm. 423, 461-470. http://dx.doi.org/10. 1016/j.ijpharm.2011.12.009.

Van de Ven, H., Paulussen, C., Feijens, P.B., Matheeussen, A., Rombaut, P., Kayaert, P., Van den Mooter, G., Weyenberg, W., Cos, P., Maes, L., Ludwig, A., 2012. PLGA nanoparticles and nanosuspensions with amphotericin B: potent in vitro and in vivo alternatives to Fungizone and Am Bisome. J. Control. Release 161, 795-803. http:// dx.doi.org/10.1016/j.jconrel.2012.05.037.

Vargas de Oliveira, E.C., Carneiro, Z.A., de Albuquerque, S., Marchetti, J.M., 2017. Development and evaluation of a nanoemulsion containing ursolic acid: a promising trypanocidal agent. AAPS PharmSciTech 1-10. http://dx.doi.org/10.1208/s12249017-0736-y.

Vyas, S.P., Gupta, S., 2006. Optimizing efficacy of amphotericin B through nanomodification. Int. J. Nanomed. 1, 417-432. http://dx.doi.org/10.2147/nano.2006.1.4.417.

Wang, T., Shen, L., Zhang, Z., Li, H., Huang, R., Zhang, Y., Quan, D., 2017. A novel coreshell lipid nanoparticle for improving oral administration of water soluble chemotherapeutic agents: inhibited intestinal hydrolysis and enhanced lymphatic absorption. Drug Deliv. 24, 1565-1573. http://dx.doi.org/10.1080/10717544.2017. 1386730.

Weber, S., Zimmer, A., Pardeike, J., 2014. Solid lipid nanoparticles (SLN) and nanostructured lipid carriers (NLC) for pulmonary application: a review of the state of the art. Eur. J. Pharm. Biopharm. 86, 7-22. http://dx.doi.org/10.1016/j.ejpb.2013.08. 013.

Wei, L., Shao, L., Feng, X., Chen, A., Zhang, Y., Wang, J., 2015. Central nervous system toxicity of metallic nanoparticles. Int. J. Nanomed. 10, 4321-4340. http://dx.doi. org/10.2147/IJN.S78308.

Wijnant, G.-J., Van Bocxlaer, K., Yardley, V., Harris, A., Murdan, S., Croft, S.L., 2017. Relation between skin pharmacokinetics and efficacy in am bisome treatment of murine cutaneous leishmaniasis. Antimicrob. Agents Chemother. 62, e02009-e2017. http://dx.doi.org/10.1128/AAC.02009-17.

WHO, 2010. Costs of medicines in current use for the treatment of leishmaniasis. http:// www.who.int/leishmaniasis/research/978_92_4_12_949_6_Annex6.pdf?ua = 1 (accessed 8.24.17).

WHO technical report series 949, 2010. Control of Leishmaniases: report of a meeting of the WHO Expert Committee on the Control of Leishmaniases. http://whqlibdoc.who. int/trs/WHO_TRS_949_eng.pdf (Accessed 2.23.18).

World Health Organization, 2017. Leishmaniasis. http://www.who.int/mediacentre/ factsheets/fs375/en/ (accessed 4.13.17).

World Health Organization, 2016a. Neglected tropical diseases. http://www.who.int/ neglected diseases/diseases/en/ (accessed 11.18.16).

World Health Organization, 2016b. Leishmaniasis in high-burden countries: an epidemiological update based on data reported in 2014. Wkly. Epidemiol. Rec. 91, 287-296. http://dx.doi.org/10.1186/1750-9378-2-15.Voir.

World Health Organization/Department of Control of Neglected Tropical Diseases, 2017. Global leishmaniasis update, 2006-2015: a turning point in leishmaniasis surveillance. Wkly. Epidemiol. Rec. 92, 557-565. http://dx.doi.org/10.1016/S01406736(09)61877.

Xie, J., Lee, S., Chen, X., 2010. Nanoparticle-based theranostic agents. Adv. Drug Deliv. Rev. 62, 1064-1079. http://dx.doi.org/10.1016/j.addr.2010.07.009.

Yukuyama, M., Kato, E., Löbenberg, R., Bou-Chacra, N., 2017. Challenges and future prospects of nanoemulsion as a drug delivery system. Curr. Pharm. Des. 23, 495-508. http://dx.doi.org/10.2174/1381612822666161027111957.

Yukuyama, M., Kato, E., Löbenberg, R., Bou-Chacra, N., 2017. Challenges and future prospects of nanoemulsion as a drug delivery system. Curr. Pharm. Des. 23, 495-508. http://dx.doi.org/10.2174/1381612822666161027111957.

Yukuyama, M.N., Ghisleni, D.D.M., Pinto, T.J.A., Bou-Chacra, N.A., 2016. Nanoemulsion: process selection and application in cosmetics - a review. Int. J. Cosmet. Sci. 38, 13-24. http://dx.doi.org/10.1111/ics.12260.

Zahir, A.A., Chauhan, I.S., Bagavan, A., Kamaraj, C., Elango, G., Shankar, J., Arjaria, N., Roopan, S.M., Rahuman, A.A., Singh, N., 2015. Green synthesis of silver and titanium dioxide nanoparticles using euphorbia prostrata extract shows shift from apoptosis to G 0 /G 1 arrest followed by necrotic cell death in Leishmania donovani. Antimicrob. Agents Chemother. 59, 4782-4799. http://dx.doi.org/10.1128/AAC.00098-15. 